\title{
MƯSÂMERETU்'L - AHBÂR'IN \\ TÜRKİYE SELÇUKLULARI DEVLET TEŞKİLATI BAKIMINDAN DEĞERİ
}

Aydın TANERİ

I.

\section{TƯRKIYY SELÇULU DEVLETI'NE DÂİR TETKIKLER}

Üzerinde yaşadığımız toprakların, vatanımızın tarihin, özellikle XI. yüzyıldan yani egemenliğimiz altına girmeğe başladığı zamandan itibaren olan tarihi son yıllardaki araştırmalar ile gelişmekte ve açıklığa kavuşmaktadır.

Bilindiği gibi, Anadolu, Büyïk Selçuklu İmparatorluğu (1040-1157)nun teşebbüsü ile başlayan ve onun vasalı olan başlıca Türkiye Selçuklu (1075-1308) ve Dânișmendiler (1071-1174) devletleri'nin gayretleri ile Bizans Imparatorluğu'ndan alınmıștır.

$\mathrm{Bu}$ devrin tarihi üstündeki perde, memleketimizde Halil Edhem ${ }^{1}$, Fuad Köprülü², Mükrimin Halil Yınanc ${ }^{3}$ in öncülüğu ve bunları takiben geniş neşriyatı ile dikkati çeken 0 sman Turan ${ }^{4}$, Mehmet

1 Kayseriyye şehri, İstanbul, 1334.

2 Anadolu Selçukluları tarihinin yerli kaynakları, Belleten VII (1943) Bizans Müesseselerinin Osmanlı Müesseselerine Te'siri Hakkında Bazı Mülâhazalar, THITM, I.) 1931).

3 Dânişmendliler, IA; Türkiye Tarihi Selçuklular Devri, Anadolunun Fethi, I, Istanbul, 1944.

4 Eserlerinin Başlıcalan: Altun-Aba Vakfiyesi, Belleten, XI (1947); Celâleddin Karatay ve Vakfiyelerî, Belleten, XII (1948); Droit terrien sous les Seldjoukides de Turqie, RE. (1948), Türkçesi: Türkiye Selçuklularında toprak hukuku, Belleten, XII (1948); Eski Türklerde okun hukuki bir sembol olarak kullanılması, Belleten, IX (1945); Ilig unvanı hakkında, TM. VII; Iktâ, IA.; Keyhüsrev I, IA; Keyhüsrev II, IA; Keykâvus I, IA; Keykâvus II, IA; Keykubâd I, Kılıç Arslan I, İA ; Kılı̧ Arslan II, IA; Kılı̧ Arslan IV, IA; Selçuk Kervansarayları, Belleten X(1946); Türkiye Selçukluarı hakkında resmi vesikalar, Ankara, 1958; Selçuklular Tarih ve TürkIslâm Medeniyetî, Ankara 1965; Süleyman-şah I, IA; Süleyman-şah II, IA. 
Köymen , Faruk Sümer ve Nejat Kaymaz ve batıda Claude Cahen ${ }^{8}$ 'in yaptıkları araştırmalar ile kaldırılmışdır.

Memleketimizde Necati Lûgal, Adnan Erzi ${ }^{9}$ Fikret Işıltan ve Tahsin $Y_{a z ı c}{ }^{10} \mathrm{~nm}$, batıda M. Th. Houtsma ${ }^{11}$ nun neşr veya tercüme ettikleri eserler de bu devri aydınlatıcı mahiyettedir.

Arapça ve farş̧adan başka Lâtin, Grek, Gürcü, Ermeni ve Suryani tarihçilerinin eserlerine istinaden incelenen Türkiye Selçuklu Devleti tarihi, araştırıcılarının metodik çalışmaları ile önümüzdeki yıllarda tamamen meydana çıkacak, bu arada Osmanlı İmparatorluğu'nun kuruluş devri daha vuzuha kavuşacak, teşkilâtına ait esaslar aydınlanacaktır.

II.

\section{MƯSÂMERETƯ'L AHBÂR'IN ÖNEMİ VE DEĞERİ}

Türkiye Selçuklu Devleti'nin başhıca kaynaklarından biri Kerimü'd-dîn Mahmud Aksarayî12'nin eseridir.

Aksarâyî -görünüşe göre- XIII. yüzyılın ilk yarısmın sonlarında doğmuştur. Onun ömrünün 1276-1323 yılları arasındaki kırkyedi yılını

5 Anadolu'nun Fethi, Diyanet İșleri Bșk. Derg. (1961); Selçuklu Devri Türk Tarihi, Ankara, 1963.

6 Anadolu'ya yalnız göçebe Türkler mi geldi?, Belleten, XXII (1958); Oğuzlar, Ankara, 1967.

7 Anadolu Selçuklu Devletinin inhitatında idare mekanizmasının rolii I, II, Tarih Araşturmaları Dergisi, 1966, 1967.; Gıyâsü'd-din Keyhüsrev II, Ankara 1958 (basılmamış doktora tezi); Pervâne Muinü'd-din Süleyman, Ankara, 1967 (basılmamış doçentlik tezi),

8 La Campagne de Mantzikert d'apres les sources musulmanes, Byzantion, IX (1934); La Premiere Penetration Turque en Asie Mineur, Byzantion, XVIII.

9 İbn Bîbi, mutassel metin: El-Evâmirü'l-Alâiyye Fi'l-Umûri l-Alâiyye, (- Ayasofya Ktp. Nr. 2985) Tıpkıbasım Ankara, 1956; nşr. N. Lugal - A. Erzi I. cilt. Ankara, 1957; A. Erzi, Ibn Bibi, IA; El Hoy, Gunyetü'l Kâtib ve Munyetü'l-Tâlib Resumü'r-Resâil ve Nücûmü'l-Fazail (Nşr. A. S. Erzi) Ankara, 1963.

10 Menâkibü'l-ârifin, (farsça metin), I. II. Ankara. 1959; Türkçe terc. Ariflerin menkıbebeleri, I - II, İstanbul , 1964, 1954.

11 Tevârih-i Al-i Selçuk,

Recueil de textes relâtifs â l'Histoìe des Seljoucides, IV, Leide, 1902.

12 Müsameretü'l-Ahbâr (Moğollar zamanında Türkiye Selçukluları Tarihi), (nşr. O s m a n T u r a n) (Farsça metin), Ankara, 1944. 
devlet hizmetinde sorumlu bir maliye memuru olarak geçirdiği, evkaf nazırlı̆ğnda bulunduğu, bir ara Aksaray kütvali (kale muhafizı) olarak görev yaptı̆̆ anlaşılmaktadır.

1323 (723)'de edebî bir farsça ile yazdığı eserini İlhanlı Devleti'nin Anadolu Valisi Timur Taş'a ithaf eden Kerîmü'd-dîn Mahmud'un bu tarihi takib eden on yıl içinde yetmiş ile yüz yaşları arasında vefat ettiği tahmin edilebilir ${ }^{13}$.

Müsâmeretü'l-Ahbâr'1 ilk olarak bütünü ile ele alan Fikret Işsltan'dır ${ }^{14}$. Işılttan eserin almanca özetini yayınlamıştır.

Bunu takiben M. Nuri Gencosman, Müsâmeretii'l-Ahbâr'1 türkçeye çevirmiştir $^{15}$. Ancak tercüme -sonunda da belirtildiği üzereıstılahların türkçeye çevrilmesi sebebi ile kıymetinden kaybetmişdir. Kitabın başında $F$. Nafiz Uzluk yazar ve eseri hakkında bilgi vermiştir ${ }^{16}$.

Aksarâyî'nin eserini heyeti umumiyesi ile ele alan, neşr ve ilim âleminin istifadesine arzeden Osman Turan olmuştur. Turan neşrinin başında eser, yazarı, eserin kaynakları ve kaynak olduğu eserleri incelemekte, yazarın bir tarihçi olmaktan ziyade, yaşadığı devrin olaylarını kaydeden bir "hâtıra müellifi" olduğunu belirtmekde ve Türkiye Selçuklu Devleti'nin inhitat ve yıkılış devirleri için başlıca iki kaynaktan biri olan -diğeri İbn Bîbî'-eserin kıymeti üzerinde durmaktadır. Turan'a göre Aksarâŷ̂, olaylanı Selçuklu- İlhanlı görüş noktasından değerlendirmekte, Anadolu'da vuku bulan isyan ve hareketlerin sebeplerini İranl müelliflerin görüşüne uygun olarak yazmaktadır. Bununla beraber eserde Moğollar'ın -işgal kuvveti olarakAnadolu'da ika ettikleri zulum ve fena idare ve devletin yıkılıs safhaları "acı tasvirler" ile izlenebilir. Bunu müteakip nâşir, Kerimü'ddîn Mahmud'un olayların sebeplerini tenkidî bir görüş̧ ile kaleme almadığına değinmektedir. 0 , yazarın çağdaşı olan bilim adamları ve kadılara dair verdiği malûmatın önemine işaret etmekte, "bu sayede Selçuk devri vakfiyelerinde adları geçen âlimleri daha iyi tanıma imkânına mâlik bulunuyoruz" demektedir. Yazarın eserinin son bahis-

13 a. g. e., s. 32 ve dv.

14 Die Seltschuken geschichte des Aksarayi, Leibzig, 1943. Bu eseri temin etmek imkânını bulamadım.

15 Selçuki Devletleri Tarihi, Ankara, 1943.

16 a.g. e. s. 4 ve dv. 
lerindeki olaylan özetlediğine ve tarih vermediğine dikkati çeken Turan, onun şahıslar hakkında vardığı hükümlerin genel olarak başka kaynaklar tarafından teyid edildiğini, ancak objektif kalamadığını, şahsî eğilimlerini sezmenin mümkün olduğunu belirtmektedir ${ }^{17}$. Turan'ın dikkatini çeken bir nokta da Aksarâyî̀nın, İbn Bîbî’nin ismini ve eserini zikretmemesidir ${ }^{18}$.

Son olarak Nejat Kaymaz "Pervâne Mu'inü'd-dîn Süleyman" adındaki araştırmasında başhıca kaynaklarından biri olan “Müsâmeretü'l-Ahbâr'ı değerlendirmiştir. Kaymaz, Aksarayî̀nin Moğol idaresi devrindeki Anadolu tarihini mufassalan kaleme aldığını açıkladıktan sonra, inhitat devrine ait araştırmasının, konusu olan otuz, otuzbeş yıllık kısım için verdiği mufassal ve sağlam bilgi ile İbn Bîbî̀yi kontrol ve ikmal ettiğini belirtmekte ve İbn Bîbî’nin sona erdiği tarihten (1280) sonra Aksarâyî̉nin Anadolu'nun yegâne yerli kaynağı olarak kaldığını ilâve etmektedir. Her iki müverrihin mukayesesine devam eden yazar, Aksarâyî'nin verdiği bilgilerin şahsî müşahadelerine dayandığını, onun genç bir divan kâtibiyken kıdemli meslekdaşı İbn Bîbî'nin orta veya ileri yaşlarda şahit olduğu olayları görmüş bulunduğunu belirtiyor. Kaymaz'a göre, Aksarâyî eserini Selçuklu Devleti'nin ortadan kalktığı ve Anadolu'nun büyük bir kısmının fiilen İlhanlı eyaleti olduğu devirde yazmışdır. Bu bakımdan İbn Bîbî’nin eseri bir Selçuklu saltanatı tarihi hüviyetindeyken, Aksarâyî̉ninki Moğol hâkimiyeti altındaki Anadolu tarihidir. Buna mukabil Aksarayînnin İbn Bîbî̀ye benzeyen tarafı ise, devletin dış ilişkileri hakkında bilgi vermemesidir. Sosyal konularda ise İbn Bîbî̀ye nazaran daha ileridir. Kaymaz, "bir aristokrat olarak" Aksarâyî’nin Türkmenler'den nefret ettiğini, Türkmen hareketlerini kurulu düzeni sarsan meşum olaylar olarak gördüğünü belirttikten sonra, değerlendirmesini, onun bir maliyeci sıfatiyle vergiler hakkında verdiği bilgilerin çokluğuna işaret ederek, sona erdirmektedir ${ }^{19}$.

Aksarâyî’nin eseri siyasî, askerî olaylar cihetinden orijinal bir hüviyeti haizdir. Türkiye Selçuklu Devleti tarihinin bir safhasında "tek kaynak" olması da ona ayrı bir hususiyet kazandırmaktadır.

17 Müsameretül-Ahbâr, s. 46 vdv.

18 a. g. e. s. 44

19 s. IX vdv. 
Bütün bu vasıflarına ilâveten Müsâmeretü'l-Ahbâr kültür tarihi kaynağı olarak da geniş malûmatı ihtiva etmektedir. Bu bakımdan eser yalnız Türkiye Selçuklular’ı için değil, İran Moğollar'ı yâni İlhanlılar Devlet'i için de önemlidir.

Biz bu yazımızda son yıllarda gelişen Selçuklu devri çalışmalarının ışığı altında Aksarâyî̀nin eserini değerlendirmeğe ve Türkiye Selçuklu Devleti'nin problemlerine değinmeğe çalışacağız.

\section{AKSARAYI'DE TÜRKIYY SELCUKLU DEVLETİ TEŞKİLÂTI ILE ILGILİ HUSUSLAR}

Türkiye Selçuklu Devleti’nin siyasî tarihi, “Kuruluş ve Büyük Selçuklu İmparatorluğu'na ve Irak Selçuklu Devleti'ne tâbiiyet”, “Bağımsızlık ve yükselme", "Moğol hâkimiyeti ve yıkılma" devri gibi bölümlere ayrulabilir.

Selçuklular'ın 1243'de Moğollar'a yenilmesi ile başlayan ve 1308 tarihine kadar süren altmış beş yıllık inhitat devri de iki safhaya ayrılabilir. 1243-1277 yılları arasındaki devir Türkiye Selçuklular'ı için hukukî ve malî şartları tedricen ağırlaşan bir Moğol vasallığı devresidir. 1277 yılından itibaren, Pervâne Mu'inü’d-dîn'in ölümü ile başlayan devrede ise normal vasallı statüsünden bahsedilemez. Zira Moğollar, Selçuklu Devleti'nin teşkilât ve müesseselerini tasfiye ederek, kendi askerî, idarî ve malî kurumlarını ikame etmişlerdir. Böylece Anadolu bir İhanlı eyaleti olmuşdur ${ }^{20}$.

Diğer tarafdan N. Kaymaz'ın isabetli teşhisi üzere, Türkiye Selçuklu Devlet'i mutlakiyetçi saltanat müesseleleri, merkeziyetçiliğe mütemayil idare tarzı, başta Abbâsî Halifeliği olmak üzere islâm devletleri ile olan ilişkileri, sultanlarının hâkimiyet sembolleri, iktâ sistemi, köle usulü, protokol ve inşâ kaideleri ile şeklen ortaçağ islâm devleti manzarası arzeder. Devlet teşkilâtı, ortaçağ Türk-İslâm devletlerine esas olan Büyük Selçuklu İmparatorluğu devlet teşkilâtının -bazı küçük ve tabii farklar ile- bir örneğidir. Türkiye Selçuklular'ı iranî ve islâmî hüviyetini tevarüs etmiş oldukları Büyük Selçuklular'-

20 N. Kaymaz. Pervâne Muinü'd-din Süleyman, S. II. 
dan daha ileri derecede eski Türk hususiyetlerini bünyesinde taşımış$\operatorname{tir}^{21}$.

Aksarayî’nin eseri söz konusu ettiğimiz meselelerden "mutlakiyetçi saltanat müesseseleri" ve "merkeziyetçiliğe mütemayil idare tarz1" hariç diğer müessese ve töreleri teyid edecek örnekleri ve bilgileri muhtevidir. Müsâmeretï'l-Ahbar'da, "mutlakiyetçi saltanat müesseseleri" ve "merkeziyetçilik" konuları ise Anadolu'nun kesin ve ağır Moğol işgali ve baskısı altında bulunması sebebi ile İlhanlı Devleti'nin Selçuklular üzerindeki otoritesi nokta-i nazarından değerlendirilmelidir.

Selçuklu idare kadrosunda Moğollar'a dayanarak mevkilerini muhafaza eden ve Moğol taraftarı klike mensub olan Aksarayî, onların yaptıkları zulüm ve haksızlıkları mazur görmek ile beraber verdiği tafsilat ile âdeta durumu okurunun takdirine birakmak yolunu da ihtiyar etmiş görünmektedir.

"Metbû devlet" veya "işgal kuvveti”" olarak Moğollar'ın Selçuklular'ın devlet teşkilâtı ve ananelerinde olduğu kadar Anadolu'nun sosyal ve ekonomik hayatında da değişiklik ika etmeleri tabiidir ${ }^{22}$. Moğol tesiri özellikle devlet teşkilâtında cebrî olarak kendini göstermiştir. Aşağıda göreceğimiz gibi başta Selçuklu sultan 1 olmak üzere ileri gelen memur ve askerlerin İhanl yarlıkları ile tâyin edilmeleri ve icabında yarguya çekilmeleri bu zümredendir.

Diğer taraftan Moğol işgalinin tabii neticesi Anadolu'nun içtimâ̂ ve iktisadî hayatında da akisler yapmıștır. Moğol zulmï ve baskısına tahammül edemeyen Etrâk' in isyanları ve kalabalık Moğol ordularının iaşe ve ibatesi Anadolu'nun sosyal ve ekonomik hayatı için yıkıcı olmuştur.

\section{A. SARAY TEŞKILÂTI VE ADETLERİ}

\section{1- a. Saltanat veraseti - Veliahdlık}

Genel olarak Türk devletlerinde hânedanın bütün üyeleri hâkimiyet hakkına maliktir. Bu bakımdan primogenetura (büyük oğlun

\footnotetext{
21 N. Kaymaz, Anadolu Selçuklu Devletinin inhitatında idare mekanizmasının rolü, I. s. 96 .

22 Moğollar devrinde Türkiye Selçuklu Devleti'nin ekonomik ve sosyal durulu için bk.: M. Akdağ, Türkiye'nin iktisadi ve içtimai tarihi, I, Ankara, 1959.
} 
tevarüs hakkı) ve senioratus (hanedan içinde yaşça en büyük olanın tahta geçme kaidesi) yoktur. Türk-İslâm devletlerinde oğulların ve kardeşlerin aynı derecede tahta geçme hakkına sahip olduklarını gösteren örnekler çoktur. Türkiye Selçuklu Devleti'nde de sultan, oğullarından birini veliahd seçer. merkezde hüküm süren sultana tâbî olmak şartı ile diğer oğullarını melik sıfatı ile ülkenin muhtelif mıntıkalarının idaresine tâyin edebilirdi. Bununla beraber "veliahd tâyini" ve "veliahdlık", sultanın vefatı halinde -Türk hakimiyet telâkkisinde ülkenin hanedanın ortak malı olması esasına göre - kardeşlerin taht üzerindeki hakkına mânî olamazdı. Veliahda bi'at edilmesi dahi, hükümdar öldükten sonra bağlayıcı hukukî mahiyetini kaybetmektedir. Zira hükümdarın ölümü ile birlikte kanunnâmeler ve hukukî tasarruflar yeni hükümdar tasdik edinceye kadar hükümden düşmekte, hukukî mesnedden mahrum addedilmektedir. Diğer taraftan tahtın "ilâhî takdir"e açık olması telâkkisinin sonucu olarak hanedan üyelerinden birinin fïlen tahtı ele geçirmesi ve onun meşruiyeti nazarî ve hukukî bir mesele olmamakda, durum emri vâki olarak kabul edilmektedir ${ }^{23}$.

Türkiye Selçuklu Devleti'nde, tahta veraset konusundaki esasları Aksarâyî’nin eserinde görüyoruz. Kılıç Arslan I., Abbâsî halifesinin dâveti üzerine Bağdad'a gitmeğe karar vermiş ve oğlu Mes'ud'u veliahd tâyin ettikten sonra dârü'l-mülk Konya'yı ona teslim etmiş$\operatorname{tir}^{24}$.

Gene eserde Kılıç Arslan II.nin en çok sevdiği oğlu Gıyâsü’d -dîn Keyhüsrev'i veliahd tâyin ettiği ve Gıyâsü'd-dîn'in babasının ölümü üzerine tahta oturduğu kayıtlıdır. Ancak Kılıç Arslan'in oğullarının en büyüğü olan Rüknü’d-dîn Süleyman'ın "razı olmadığı" ve fikrine iltihak etmeyen kardeşlerini öldürttüğ ${ }^{25}$, diğerleri ile ittifak ettikten sonra Konya'yı muhasara ve Gıyâsü'd-dîn

23 H. Inalcık, Osmanlılarda saltanat verâseti usulü ve Türk kâkimiyet telâkkisiyle ilgisi, SBFD, XIV (1959) S. 69, ve dv.

24 Aksarayî, s. 28 - 29. Yazara göre Abbâsi halifesi, Kılıç Arslan I. a yolladıği elçi ile Bağdad'a gelmesini ve "Acem Saltanatı"n ona vereceğini vaad etti. M. Köymen, Kılıç Arslan'ın haleflerinin Anadolu kıt'ası ötesinde, doğuda, maceralar peşinde koşmaktan ise Türkiye birliğini temin yolunda faaliyete geçmesini "utopist siyaset" den "realist siyaset" e geçiş olarak tavsif etmektedir. Zira, bilindiği gibi, Süleyman Şah I. ve Kılı̨̧ ArsılanI. in doğuda yaptıkları teşebbüsler başarısızlık ile sonuçlanmış ve her ikisi de hayatlarımı bu yolda kaybetmişlerdir. (Selçuklu Devri Türk Tarihi, S. 112 - 113).

25 Aksarâyî, s. 31 . 
Keyhüsrev'i şehri terk etmeğe icbar ettiği yazılıdır ${ }^{26}$.

Aksarâyî -ülüşs sistemi esaslarına uygun olarak- Kılı̣ Arslan II. nin ülkeyi oğulları arasında taksimine de değinmiş ${ }^{27}$ ancak bu işlemin nedenleri hakkında fikir beyan etmemiştir ${ }^{28}$. Böylece Selçuklu Devlet'i biri sultanın kendi ikametine tahsis etmiş olduğu payitaht Konya ile ona tâbî civar bölgeyi içine alan metbû; on bir tanesi de diğer şehirlerde melik unvanı ile hüküm süren şehzadelere ait olmak üzere tâbî on iki devletten müteşekkil bir manzume haline inkilab etmiştir ${ }^{29}$.

Aksarâyî̀de Süleyman-Şâh II. nin ölümünü takiben ümerânın altı yaşındaki oğlu İzzü'd-dîn Kılı̣ Arslan'ı tahta çıkardığı kayıtlıdır. Ancak emîrlerden bir kısmı, gizlice Zekeriya Hâcib'i, İstanbul'a iltica etmiş olan eski sultan Gıyâsü'd-dîn Keyhüsrev'e gönderdiler ve onu Konya'ya dâvet ettiler ${ }^{30}$. Böylece devlet erkânının desteğini temin eden Gıyâsü'd-dîn ikinci defa tahta oturdu ${ }^{31}$.

1243 yılında Kösedă̆ savaş'ında Moğollar'a yenilen ve 1245 'de ölen Gıyâsü’d-dîn Keyhüsrev II. in üç oğlu vardır. Diğer kaynaklardaki bilgiye uygun olarak bunlar, Aksarayî̀ye göre İzzü'd-dîn Keykâvus, Rüknü'd-dîn Kılı̨̧ Arslan ve Alâü'd-dîn Keykûbad adını taşıyorlardı. Gıyâsü'd-dîn, sağlığında Abhaz melikesi Gürcü hatun (Melike Rusudan) un kızından doğan oğlu

26 Aksarayîs. $30-31$.

27 Aksarayî, s. 30. Kılıç Arslan'ın devleti onbir şehzâdeye taksimi için bk. O. Turan, Süleyman-Şah I. IA.

28 Kılıç Arsılan'ın ülkesini taksim nedeni hakkında tarihçilerin görüşlerini özetleyen N. Kaymaz. olayda zorlayıcı faktörlerín rolünün bulunduğunu düşünmenin isabetli olacağını yazıyor. Ona göre, uzun saltanatı haricî ve dahilî mücadeleler ile geçen ihtiyar sultanın, arzusu ile bu taksimi yapması güçtür. Kaymaz, Kılı̣ Arslan'ın bu sırada şahsî otoritesini kullanmak insiyatifinden mahrum göründüğünü ilâve ediyor (a. g. e. S. 113).

29 Kaymaz, a. g. e. S. 113.

30 Zekeriyâ Hâcib'in Istanbul'a gidişi ve Keyhüsrevile teması İbn Bîbî'de mufassaldır (Lugal - Erzi, S. 112 - 116).

31 Aksarâyi, eserinde cülûs ve biat merasimine dair tafsilât vermemişdir. Meselâ, Gıyâsü'd-dîn Keyhusrev II, e beyler biat ettiler. Şemsü'd-dîn Altun-Aba ve Cemâlü'd-dîn Ferruh onu sağ ve sol ellerinden tutarak tahta oturttular. Sonra el öpmek, para saçmak gibi âdetler yerine getirildi. (Kaymaz, Mekanizma, II. S. 32) Ayrica bk. Turan, Selçuklular, S. 296) 
Alâü'd-dîn'i neseb ıtibarı ile kardeşlerine tefevvuk ettiğinden ${ }^{32}$ veliahd tâyin etmişdi. Sultanın ölümünden sonra iktidarı fiilen elinde tutan Celâlü'd-dîn Karatay, beylerbeyi Yavtaş ve diğer emîrler ile anlaştıktan sonra üç şehzadeyi müşterekn tahta çıkarmışlardır ${ }^{33}$.

Görülüyor ki, Türkiye Selçuklu Devleti’nde hükümdarın cülûsu için, devlet ileri gelenlerinin bir "meşveret meclisi" teşkil ederek, fikir teatisinde bulunmaları ve ekseriyet ile seçimi kazanan hanedan üyesinin tahta geçirilmesi esası hâkimdi. Bunda da Türk devletlerinin hususiyeti olan askerî bünye rol oynamaktadır. Zira cülûs'da rol oynayan en mühim faktör maddî kuvvettir. Böylece "sultan seçimi" bu maddî kuvvetin temsilcisi olan devlet erkânının iradesine bağlı idi. Bu durumda "veliahdlık", "büyük oğul veya büyük kardeş hukuku" gibi hususlarn dikkate alınıp alınmaması tesadüfe kalıyordu ${ }^{34}$

32 Anne tarafından asaletin hanedan üyeleri arasında ne gibi etkiler yaptığını, Kılı̨̣ Arslan II'ın, Bizans Imparatorunun karısının kızkardeşinden doğan oğlu küçük şehzade Giyâsü'd-dîn Keyhüsrev'i veliahd tâyin etmesi olayında görüyoruz. Çağdaş Bizans yazarı Choniates Rüknü'd-din Süleyman'ın kardeşi Keyhüsrev'e şiddetli hareket etmesinin nedenleri arasında Gıyâsü'd-dîn'in annesinin hırıstiyan oluşu ile de ilgili bulmaktadır. (Kaymaz, idare mekanizması I. S. 118). O. Turan, bu durumun Keyhüsrev'e kin beslenmesine sebeb olması ihtimalini kabul etmemektedir (Les Souverain Seldjoukides et leurs sujets non-musulmans St. I. sl. 80).

33 Aksarâyî, S. 36. Yazar üç kardeşin müştereken tahta cülûsu tarihi olarak babaları Gıyâsü'd-dîn Keyhüsrev II. in ölüm tarihi olan (647-1245) yılını vermektedir. Bu yıl annesi bir rum papazının kızı olan büyük şehzâde İzü̈d-din yine, bir rum kızından dünyaya gelen ortanca şehzâde Rüknü'd-dîn ile Gürcü hatun'dan doğan ve doğar doğmaz veliahd tâyin edilen Alâü'd-din altı - yedi yaşlarında idiler . Bu sırada Türkiye Selçuklu Devleti'nde bütün idarî yetkiler vezîr Şemsü'd-dîn İsahanî'nin elinde idi. Bu zat, başta emir Celâlü'd-dîn Karat a y olmak üzere ileri gelen devlet ricali ile anlaşarak veliahdı ve ortanca şehzadeyî tutan zümrelere rağmen İzzü'd-dîn Keykâvus'ü kolayca tahta oturttu. Ancak 1246 da Karakurum'a giden melik Rüknü'd-dîn Kılı̣ Arslan'ın maiyetindekiler ellerinde Göyük Han'ın yarlıkları ve berabererinde ikibin Moğol askeri`olduğu halde Anadolu'ya döndüler ve Kıılı̨ Arslan'ı Sivas'ta tahta oturtup Sultan ilân ettiler. Kıılı̣ Arslan'ın maiyeti, hanın yarlıkları hükmüne göre Keykâvus'un saltanattan uzaklaştırılmasını ve vezîrin katledilmesini temin için Konya'ya adam gönderdiler. Vezir öldürüldü(1249). Bu durumda †zzü'd-dîni korumak ve ortaya çıkan meseleleri çözmek K a a a a y'ın omuzlarına yüklendi. Kar at a y herkesi tatmin edecek bir hal şekli bulmuş ve üç kardeşin birden tahta oturmasını teklif etmişdir. Bunun üzerine Rüknü'd-dîn ve Izzü'd-dîn tarafları arasında başlayan mücadele ikincinin üstünlüğü ile sonuçlanmış ve Rüknü'd-dîn esir edilmiştir. Ancak Karatay kardeşleri ve taraftarlarını. barıştırmış ve üç kardeşi müştereken tahta oturtmuş, kendisi de Atabek-i Rum unvanı ile üçünün atabeyi olmuştur. (Kaymaz, Pervâne, S. 13 - 20).

34 Kaymaz, a.g. e, S. 100. 


\section{b. Sultanların yarlık ile tâyini}

Anadolu'nun Moğol tahakkümü altına girmesi ile Selçuklu Hanedanı mensuplarının tahta cülûsu da yeni durumun gerektirdiği şartlara -başlangıçda Moğol kumandanlarının, bilâhare İlhanlı hükümdarının iradesine- bağlı oldu. Sultanlığa tâyinde, Selçuklu devlet ricâlinin menfaat hesapları -İlhanın yarlığı yeni sultanı tasvib ettiği takdirdeuygun bir ortam bulabiliyordu. Bu bakımdan yeni devirde Selçuklu sultanları, Anadolu'da vazifeli yüksek kademedeki İlhanlı ricalinin de katıldığı girift entrikaların sonucunda tahta çıkıyor, mevkilerini muhafaza edebilmek için de sayısız güçlükler ile karşılaşıyorlardı. Bu devirde İlhanlı nüfuzunun kesafetine en bariz misâl de, sultanların yüksek makam sahipleri için tanzim ettikleri tâyin menşurlarının İlhanın tasdikine arzetmeleri zorunluluğunu duymalarıdır ${ }^{35}$.

Müsâmeretï'l-Ahbâr'da sahifeler boyunca yarlık ile veya bazen de Moğol kumandanlarının tasvibi ile sultan olan Selçuklu hanedanı mensuplarının kritik durumları anlatılmaktadır. Nitekim Kılıç Arsılan IV.- pervâne Nizâmü'd-dîn Hurşid ve Mu'înü'd-din Süleyman'in delâleti ile Bayçu Noyan'a götürülmüş ve onayı alındıktan sonra sultan ilân edilmiştir ${ }^{36}$. Sultan İzzü'd-dîn Keykâvus II. ise Hulagu'nun tevcih ettiği bir yarlık ile Selçuklu tahtına geçti. Daha sonra Kılıç Arslan da beraberinde Mu'inü'-dîn Pervâne olduğu halde Hulagu'ya gitti. Pervâne, Hulagu'ya hitaben “Şerî'at-1 müslümanî”ye göre Rûm diyarı'nın iki kardeşe taksim edilmesi gerektiğini, bu şekilde bir idare şeklinin metbû hükümdara olan mükellefiyetleri yerine getirmekte kolaylık sağlayacağını ve her birinin memleketin gelişmesi için daha fazla gayret göstereceklerini söyledi ${ }^{37}$. Pervâne'nin ricasını kabul eden Hulagu iki kardeş -yâni İzzü'd-dîn Keykâvus II. ve Kılıç Arslan IV. -adına yarlıklar düzenleyerek ülkeyi taksim etmiştir ${ }^{38}$.

Kılı̧ Arsıan IV. 'ün öldürülmesini takiben başta Pervâne olmak üzere Selçuklu Devlet'i erkânı maktul sultanın altı yaşındaki

35 Aksarâyî, s. 138

36 Aksarâyî, S. $42-43$.

37 Pervâne, yukarıda belirttiğimiz Türk hâkimiyet telâkkisinden bahsetmemiş, bununla ilgisi olmayan islâm miras hukukundan bahsetmişdir. Kaldı ki ileri sürdüğü "şer'iat-ı müslüman̂̀" islâmiyette hususî hukuk sahasında mer'idir; âmme hukuku ile ilgisi yokdur.

38 Aksarâyî, S. $61-62$. 
oğlu Gıyâsü'd-dîn Keyhusrev'i tahta çıardılar ${ }^{39}$. Ancak bu işlemin ilhanın iradesi tahtında yapıldığı muhakkaktır.

İlhan Ahmet Teküdar ise Anadolu'yu - Hulagu'nun yaptığ gibi- ikiye bölmüş, Gıyâsü'd-dîn Keyhusrev ve Giyâsü'd-dîn Mesud arasında taksim etmişdir. Ancak nâib-i sultan Mücirü'd-dîn Emîrşah'ın politik faaliyeti sonucu Gıyasü'd-dîn Keyhûsrev tasfiye edilmiştir ${ }^{40}$. Gazan Han ise bütün Selçuklu ülkesini -Alä̈’ddîn Keykubad III. e bir yarllk ile tevcih etmiştir ${ }^{41}$. Gene Gazan Han, Alâü'd-dîn Keykûbad III.ı tahttan uzaklaştırdıktan sonra bir yarlık ile Giyâsü'd-dîn Mes'ud II. ${ }^{42}$ u sultan olarak tâyin etmiştir ${ }^{43}$.

\section{c. Payitaht}

Müsâmeretü'l-Ahbar'da Kılı̨̧ Arslan I. devrinde -diğer çağdaş kaynakların verdiği bilgiye uygun olarak, -payitahtın Konya olduğu yazılıdır ${ }^{44}$. Keza İzzü'd-dîn Keykâvus II. de Konya'yı merkez ittihaz etmiştir. Bu sırada Kılı̧ Arslan IV. ise "merkez-i saltanat" olarak Tokat'1 intihab etti. ${ }^{45}$

Esasen Selçuklu sultanları'nın Anadolu'nun hemen bütün şehirlerinde tahtları vard ${ }^{46}$. Hükümdarlar geçici veya devamlı olarak Konya'yı terkedip intihab ettikleri bir şehirde ikamet ediyorlardı ${ }^{47}$. Aks arây î'nin verdiği bilgiden anladığımiza göre, İzzü'd-dîn Keykâvus da bir müddet için Konya'yı bırakmış ve Antalya'da oturmuşdur ${ }^{48}$.

39 Aksarâyî. S. 87. Bu sırada Giyasü'd-dîn Keyhusrev, İbn Bîbî'ye göre iki buçuk yaşında idi. Fazla bilgi için bk. Kaymaz, Pervâne S. 96 ,

40 Aksarâyî S. 138

41 Aksarâyî, S. 278 - 279.

42 Akdağ, Müneccimbaşı'ya istinaden son Selçuklu sultamı Gıyâsü'd-dîn Mes'ud'un öldüğü zaman sultan dahi olmadığı ihtimah üzerinde durmaktadır (Türkiye'nin iktisadi ve içtimai tarihi, I. S. 129, Not: 2)

43 Aksarayî, S. 291.

44 Aksarâyî, s. 28 - 29.

45 Aksarayî, S. 49 ve 62 .

46 Görünüşe göre Büyük Selçuklular'da ve Hârizmşahlar Devletleri'nde de ülkenin başhica şehirlerinde tahtlar vardı. Sultanlar seyahatlerine bu tahtları kullanıorlardı. (Nesevî, Histoire du Sultan Djelal Ed-Din Mankobirti, Paris, 1895, S. 395)

47 Meselâ Alâü'd-dîn Keykubâd I. de kışları Antalya veya Alâiye'de geçirirdi. Bu şehirler kışlık payitaht durumunda idiler. Sultan yaz mevsimini Konya, Kayseri ve Sivas'da geçiririyordu (Kaymaz, İare Mekanizması, II S. 47).

48 Aksarâyî, S. 65 . 


\section{Hükümdar ve hâkimiyet sembolleri}

Aksarâyî̀nin sahifeler boyunca verdiği dağınık malûmattan anladığımıza göre, Selçuklu sultanı, menşurları ilhan tarafindan tasdik edilmesi gereken, ilhana "ubudiyet"ini arzeden ${ }^{49}$, gerektiği zaman Anadolu içindeki seyahatlerinde ona refakat eden ${ }^{50}$, bazen Moğol noyanlarina mazeret beyan edip af dileyen ${ }^{51}$, ikamete mecbur edilen ${ }^{52}$, yarguya çekilen ve dayak cezası ile tecziye ${ }^{53}$ ve hatta katledilen zavallı bir hükümdardır ${ }^{54}$.

Selçuklu sultanının Moğol protokolundaki yerine gelince: $\mathrm{O}$, ilhan tarafından kabul edildiğinde "ümerâ-i tümen" e nazaran daha üst bir mevki işgal ediyordu ${ }^{55}$.

Hükümdarın hâkimiyet sembolü olan unsurlar manevî ve maddî olarak ikiye ayrilabilir. Manevî unsurlar, unvanlar ve hutbe; maddî unsurlar ise taht, tac, sikke, nöbet, çetr, turaz, bayrak, tuğ, kemer, çadır, yïzük v.s. dir.

Genel olarak, hâkimiyet alâmetlerine dair malûmatın mevcud olduğu Aksarâŷ̂’de sultanların unvanlarına dair bilgi yoktur. Ancak Abbâsî halifesi tarafından Süleyman-Şah II. ye sultan unvanı verildiğine dair bir kayıt bulunmaktadır ${ }^{56}$.

Hutbe'ye dair ise iki kayıt vardır: Bunlardan birincisi Kılı̨̧ Arslan IV., İzzü'd-dîn Keykâvus II. ve Alâü'd-dîn Keykûbad II.'nin ümerâ tarafindan müștereken tahta çıkarıldıklarında adlarına hutbe okunduğu hakkındaki kayıt ${ }^{57}$, diğeri saltanat davasına

49 Aksârayî, s. 134.

50 Aksârayî, S. 168 .

51 Aksarâyî, S. $206-207$.

52 Aksarâyî, S. $235-236$.

53 Aksarâyî, S. 291.

54 Akdağ, Selçuklu Sultanları'nun düştükleri zor durumu belirtmişdir (a. g. e. S. 161).

55 Aksarâyî S. 61. Diğer taraftan Reşidü'd-dîn'in yazdığına göre Hulagu, Bayçu Noyan ile savaştığı için İzzü'd-dîn Keykâvus II. e kızgındı. Bilhassa Bağdad'm zaptından sonra endişeye düşen Izzü'd-dîn, imâl ettirdiği bir çizmenin tabanına kendi resmini nakşettirdi ve Hulâgu tarafindan kabul edildiğinde, hediye takdimi sırasında çizmeyi de ilhana verdi ve yer öperek "Arzum, padişahın mübarek ayağı ile bu bendesinin başını ululaştırmasıdır" dedi. Bunun üzerine Hulagu yumuşamış ve sultanı affetmiştir (Histoire des Mongols de la Perse (nşr. Quatremere), Paris . 1836. S. 322 - 323.

56 Aksarâyî, S. 56

57 Aksarâyî, S. 37 . 
kalkışan Cimri'nin Konya'ya hâkim olduktan sonra adına hutbe okunduğu şeklindeki ifadedir ${ }^{58}$.

Maddî unsurlardan olan $\operatorname{taht}^{59}$ ise çağdaşı diğer kaynaklarda olduğu gibi Aksarâyî'de en fazla zikredilen hâkimiyet sembolüdür. Bazan serir ${ }^{60}$ kelimesi ile de ifade edilen taht ekseriya "saltanat" ile beraber "taht-1 saltanat ${ }^{61}$, "serîr-i saltanat" veya "taht-1 Süleymanî ${ }^{62}$ " şeklinde kullanılmıştır. Taht, ancak cülûs münasebeti ile zikredilmiş, olaylar veya hükümdarın kabulleri vesilesiyle bahis konusu edilmemiştir.

Müsâmeretü'l-Ahbâr'da sikke de bahsi az geçen hâkimiyet sembollerindendir. Yukarıda hutbe münasebeti ile zikrettiğimiz üç kardeşin müşterek saltanatında sikke darbedildiğinden ${ }^{63}$ bahsedilmektedir. AyAyrıca Cimri'nin de sikke bastırdığına dair ${ }^{64}$ bir kayıt vardır.

Eserde, nöbet'e ait de bazı kayıtlar bulunmaktadır. Meselâ, "Bağımsızlık ve yükselme devri" hükümdarlarından Rüknü'd-dîn Süleyman-şah II. ın günde üç nöbet çaldırdığını ${ }^{65}$, Moğol tahakkümü altındaki Selçuklu sultanlarının ise -ileride göreceğimiz üzere İlhanlı hükümdarlar ${ }^{66}$ gibi- beş nöbet çaldırdıklarını görüyoruz. Gerçekten, Aksarâyî üç kardeşin müşterek saltanatlarında beş nöbet çalındığını kaydettikten sonra ${ }^{67}$, gene Kılı̨̧ Arsılan IV'ın "beş nöbet-i pâdişâhane" çaldırdığın ${ }^{68}$, saltanat üzerinde hak iddia edip, bir ara Konya'da tahta çıkan Cimri'nin de beş nöbet çaldırdığını kaydediyor ${ }^{69}$. Eserin son kısımlarında ise, Moğol kumandanı Abuşga'nın, Alâü'd-dîn Keykûbad III. Sivas'dan Yabanlu yaylağı'na getirttiğinde, onun

\footnotetext{
58 Aksarâyî, S. 124 .

59 Aksarâyî, S. $31-32$.

60 Aksarâyî, S. 101, 176.

61 Aksarâyî, S. $28,29,33,40,49,62.71 .87$.

62 Aksaraâyi. S. 124. Yazar. devletin kurucusu Süleyman Șah I. 1 kastetmiştir.

63 Aksarayî, S. 37 .

64 Aksarâyî, S. 124. Bk. O. F. Sağlam, Simdiye kadar görülmeyen Cimri Sikkesi, Belleten, IX (1945.)

65 Aksarâyî́S. 31

66 Ilhanhlar Olcayto devrinden itibaren yedi nöbet çaldılar (Uzunçarß̧ılı, Medhal,

67 Aksarâyî, S. 37 .

68 Aksarâyî, S. 71 .

69 Aksârayî, S. 130 .
} S. 221). 
için beş nöbet çaldırdığı kayıtlıdır ${ }^{70}$.

Selçuklu sultanlarının bayrakları râyât-ı saltanat ${ }^{71}$ ve Abbasî halifelerinin sultanlara verdikleri çetr (şemsiye $)^{72}$, livâ (sancak $)^{73}$ ve hil'at'a ait kısa bilgiler vardır. Abbasî halifesi tarafından Süleyman-şah II.a hâkimiyet sembolü olarak çetr ve livâ verilmiştir ${ }^{74}$. Keza halife, Mesud I.a livâ meyanında teşrif (hil'at) de verdi ${ }^{75}$. Selçuklu Devleti'nin Moğol hâkimiyetinde olduğu surada ise, Gazan Han, Alâü'ddin Keykûbad III. a bir yarlık ile sultanlığı tevcih ettikden sonra kös, sancak, berk ve 'alem'de vermiştir ${ }^{76}$.

Sultanların çadırlarının -Abbasîler'inki gibi- siyah renk'te olduğuna şüphe yoktur. Aksaray î'de Sultanların $t u \breve{g}^{77}$, yüzü̈k ${ }^{78}$ ve $k e$ mer'lerine ait bilgi yotdur.

70 Aksarâyî, S. 286. Nöbet için Bk. Turan, Selçuklular, S. 294. Köprülü, Edebiyai araşturmaları, Ankara, 1966. s. 110 ve dv. İA.

71 Aksarâyî S. 71. Bayrak için Bk. Uzunçarşılı, Medhal, S. 79; Köprülü, Bayrak,

72 Uzunçarşılı, Medhal a. g. e., S. 77.

73 Uzunçarşılı, Medhal, S. 79.

74 Aksarayîs. 31 .

75 Aksarâyî, s. 29. Abbasî Halifesi sultan Keykâvus, I. a çetr, sancak, siyah imâme, zırhlı elbise, kamçı ve kılıç gibi hâkimiyet elâmetleri yolladı (Turan, Keykâvus, I. İA).

76 Aksarây î, S. 279. "Alât-ı mulûkiyye" denilen sembollerin tamamı menşur, bayrak, kulıç, at ve davul'dur (H. Ínalcık, a. g. e. S. 77). Batu han ise Ghryâsü'd-dîn Keyhusrev, II. e, onun Bayçu ile yaptığı anlaşmayı onay mahiyetinde yarlık, kılıç, yay, sadek, külâh, elbise samur gibi hediyeler yolladı. Böylece Türkiye Selçukluları'nun İlhanlı Devleti'ne tâbiliği resmî ve hukukî olarak kesinleşdi (Kay maz, Pervâne, S. 10). İbn Bibi'ye göre Batu Han Keykâvus II.'e yay göndermişdir. (Turan, Eski Türkler'de okun hukukî b:r sembol olarak kullanılması Belleten, IX, s. 311 .

77 Genel olarak islâm kayanklannda tuğa dair bilgi azdır. A. İnan. Tuğ - Bayrak (Sancak) adlı yazısında tuğ terimine ilk defa VIII. yüzyılın ortalarında bir uygur hakam adına dikilen yazıtta rastlandığını yazmaktadır. M. Kâşgarî‘.... tuğ dokuzdan artık olamaz. Çünkü dokuz sayısı ile uğurlanırlar... Beçkem -alamet ise savaş gününde yiğitlerin belge olmak üzere takındıkları ipek parçası ve dağ sığırı kuyruğu Oğuzlar buna perçem derler" şeklinde yazdı. Inan, tuğ ve bayrağın, Türkler için daima millî mukaddesattan sayıldığını, zira onda "cedd-i âla"'mn koruyucu ruhu ve zafer tanrısı bulunduğuna inandıklarını, islâmî devirlerde bile sefere çıkarken eski dinî âyinin yapıldığın, bugünkü "bayrak töreni" nin eski tuğ âyininin gelişmiş bir şekli olduğunu yazyyor (Türk Kültürü Dergisi, Sayı: 46, S. 871 - 875).

78 Selçuklu hükümdarının yüzüğünü verdiği kimse onun tarafında: görevlendirilmiş demektir. Emir Sadü'd-dîn Köpek, Keyhüsrev II. den atabey Ay-Aba'nun katli için ferman aldıktan sonra parmağında sultanın yüzüğ̈ olduğu halde divan toplantısına girmiş ve atabeyi ak sakalından yakalayıp dışarı çıkardıktan sonra katlettirmiştir. Gene Köpek aynı şekilde Tâeü'd-dîn Pervâne'yi de ortadan kaldırdı. (Uzun çarşılı, Medhal, S. 81; Kay maz, İare Mekanizmast, II. S. 48 , ve 51). 
Diğer taraftan Selçuklu sultanlarına seyahatleri sırasında, maiyetleri (hayl ve haşem) refakat ediyor, kös (davul), sancak, berk (teçhizat) ve ${ }^{\circ}$ alem bulunduruyorlardi ${ }^{79}$.

\section{Hükümdarm maiyeti}

Türkiye Selçuklu Devleti sultanının maiyetinde emir-i hâcib, üstâdü'ddâr, çaşnigâr, emir-i cândâr, emir-i silâh, emir-i meclis, emir-i şikâr, emï-i âhur, emir-i 'alem, emir-i devât, emir-i mahfil, câme-dâr, şarab-dâr, taşt-dâr, havâyic-i sâlâr, üstâdü's-saltana ve serhengler vardı ${ }^{80}$.

Saray erkânı, Aksarayî'de genel olarak, "zümre-i havâss ve hadem" veya "ümerâ-i hâss" ş2 şeklinde zikredilmişdir. "havâs" "\$3 tâbiri de hükümdarın maiyetindeki saray vazifelilerine tekabül eder. Genel olarak Türk-İslâm devletlerinde bunların hepsi, gulâm sistemi'ne göre yetiştirilmiş askerî sınıf mensubları olup, emîr rütbesini taşıyorlardi.

Hâcibler ${ }^{84}$ saraydaki teşrifatı organize ve idare eden, özellikle hükümdarn kabulleri sırasında protokol vecibelerini yerine getiren ve hükümdar ile devletin ilerigelen erkânı arasında irtibatı temin cden görevlilerdir. Aksarâŷ̂'de bu mansıb Hâcib Zekeriya ${ }^{85}$ ve emir-i hâcib (baş hâcib) Mu'inü'd-dîn Süleyman ${ }^{86}$ vesilesi ile geçmekte, görevleri hakkında bilgi bulunmamaktadır ${ }^{87}$.

Sultanın atlarma ve ahırlarına nezaret etmek ile görevli emir- $i$ $a h u r^{88}$ un ve hükümdarın elini yıkarken ibrik ve leğen tutup bunları

79 Aksarâyî, S. 279.

80 Uzunçarşılı, Medhal, S. 85.

81 Aksarâyî. S. 42, 133.

82 Aksarâyî, S. 176 .

83 Aksarâyî, S. 130

84 Hâcib için bk. Köprülü, Hâcib, İ-A; N. Kaymaz, Büyük Selçuklu İmparatorluğu'nda $H a ̂ c i b-i$ büzürg'ün en büyük saray memuru ve devlet teşkilâtında vezîrden sonra en yüksek dereceye sahip olduğunu belirttikten sonra Türkiye Selçukluları'nda bu fonksiyonunu kaybettiğini ilâve ediyor (Pervâne, S. 188).

85 Aksarâŷ̂, S. 32; bu zat için bk. İbn Bîbî (Lugal-Erzi, S. 112).

86 Aksarâyî S. 41 .

87 F. Sümer,Irak Selçuklu hükümdarı Mes'ud (1134-1152) un Azerbaycan'da rastladığı Beğ-Arslan adlı çok yakıșıklı bir gence Has-beğ unvanım verdiğini ve onu hâcib yâni bütün emîrlerin başı yaptığım işaret ediyor (Oğuzlar, S. 129).

88 Aksarâyî, S. 42. 70, 74, 75). 
muhafaza ile görevli taşt-dâr ${ }^{89} \mathrm{In}$, sultanın av silâhlarına bakan, ava çıtığında ona refakat eden, aynı zamanda manevra mahiyetindeki avları organize ve av sahaların tesbit eden emirü's-sayd ${ }^{90}$, hazinenin gelirlerinden ve vergilerinden belli bir miktar alıp, sarayın firınlarına, mutfaklarına, ahırlarına, saraydaki görevlilere sarf ve tahsis eden ûstâdï'd-dar ${ }^{91}$ mansıbları eserde zikredilmiş, fakat vazifeleri hakkında bilgi verilmemiştir. Ancak bu son makama gelen Eminü'd-dîn'in evvelce emir-i dâd'llkta bulunduğu ve üstâdï'd-dâr'lık ile beraber uhdesinde mütevellî-i evkâf-ı memâlik mansıbını da bulundurduğu anlaşılmaktadır $^{92}$. Böylece Selçuklu devri devletlerinde "bir şahsın birden fazla memutiyeti olabilmesi” esasına dair örneğe Aksarâyî̉nin eserinde de rastlyoruz.

Moğol işgali altındaki Anadolu'da çocuk yaşta sultanlar tahta çıkarılıyor, eğitimleri için de öğretmen tâyin ediliyordu. Gerçekten Giyâsü'd-dîn Keyhûsrev III. altı yaşında tahta geçtiğinde, Pervâne Mu'inü'd-dîn seçkin bir kişi olan kadı Nurü'd-dîn Yanbû ĝ̣̂’yi sultanın talim ve terbiyesi ile görevlendirdi ${ }^{93}$. Bu mansıbın adı üstâdï's-saltana ${ }^{94}$ dır.

Münhiyan ${ }^{95}$ sultanın emrinde olup, muhaberatta istihdam edilen habercilerdir.

Diğer saray görevlileri hakkında eserde bilgi yoktur.

\section{Hükümdarın sarayı ve kabulleri}

Sultan kabullerini saray veya çadırda yapar. Saray, hükümdarın resmî ve hususî hayatının ceryan ettiği ve bu hayatın icap ettirdiği teşrifatı yerine getirmek ile muvazzaf kimselerin bulunduğu binaya denir. Saray selâmlık ve harem olmak üzere başhca ikiye ayrilır. Harem, sultanın nikâhlı karıları ve câriyelerinin bulunduğu kısımdır. Selâmlık,

89 Aksarâyî, S. 42 .

90 Aksarâyî S. 126. Selçuklularda av hakkında bk. Köprülü, Edebiyat araştırmaları, S. 79-84.

91 Aksarâyî, S. 88 .

92 Ayn yer.

93 Ayn yer.

94 Turan, Ústâdü's-saltana tâyinine ait bir belge neşretmişdir (Vesikalar, S. 38; Vesika, LIV); İbn Bîbî, atabeylerin de meliklere ögretmenlik yaptığmı yazıyor (Lugal-Erzi, S. 53).

95 Aksarâyî, S. 86. 
hükümdarın resmî ve gayrı resmî kabullerini yaptığı bölümdür. Selçuklu devri kaynakları harem hakkında pek az bilgi verirler ${ }^{96}$.

Türkiye Selçuklu sultanlarının saraylarına dair Müsâmeretü'l-

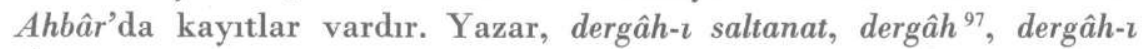
$\hat{A l-i}$ Selçuk $^{98}$, kasr ${ }^{99}$ ve saray ${ }^{100}$ tâbirlerini kullanmaktadır. Verilen malûmattan ülkenin başlıca şehirlerinde -Konya, Aksaray, Tokat, Antalya, Sivas v.s.-saraylar bulunduğu anlaşılmaktadır. Hükümdar seyahate çıtı̆̆ında ona bârgâh-ı dehliz veya serâperde-i hüsrevâne kuruluyordu. Sultan İzzü'd-dîn Keykâvus II. için Konya'nun Ruzbe ovası'nda "bargâh-ı dehlîz" kurulmuşdur ${ }^{101}$. Moğol kumandanı Abuşka da, Yabanlu yaylağı'nda ${ }^{102}$ Sultan Alâü'd-dîn Keykûbad için dehliz-i bârgâh ve serâperde-i hüsrevâne kurdurdu ${ }^{103}$.

Menfadaki Selçuklu sultanlannın ikametgâhlarına dair de Aksarâŷ̂’de bilgi vardır:

İzzü'd-dîn Keykâvus II. Bizans'a iltica ettiğinde İmparator Mihael Paleologos VIII. ona "makam-ı hüsrevâne" tahsis etmiş$\operatorname{tir}^{104}$. Bu da sultanın unvanı ile mütenasib bir binada misafir edildiğini gösterir ${ }^{105}$. Ancak Keykâvus'un Bizans tahtını ele geçirme teşebbüsü akim kalınca bir kalede ikamete mecbur edildi ${ }^{106}$. Bilindiği gibi, K e ykâ-

96 İbn Bîbî, Giyâsü'd-dîn Keyhüsrev I. in birinci saltanatının sonunda Konya'y1 terke icbar edildikten sonra, melikin misafiri olarak gittiği Amid'de "harem-i hûmayun"da kızkardeşi ile görüştüğünü ve aralarındaki muhavereyi yazar (Lugal - Erzi, S. 65 - 66). Gene İbn Bîbî, Kılı̣̣ Arslan II ile oğlu Gıyâsü'd-dîn Keyhüsrev'in "serâçe-i halvet"deki görüşmelerini mufassalan anlatır (a. g. . S. 20).

97 Aksarayî, S. 89.

98 Aksarâyî, S. 132.

99 Aksarâyî, S. 124.

100 Aksarâyî, S. 86. 127 .

101 Aksarâyî, S. S. 69.

102 Yazarın kasdettiği Kayseri-Elbistan arasında Karahisar ovası'nda Yabanlı bazarı'nm kurulduğu yer olmalıdır. $O$ devirde Anadolu'da milletler arası ticaretin gelişmesi neticesinde şehirlerin uzağında yabanda kurulan bu pazar (panayır-foir) lar Yabanlu (ğ) adını alıyorlardı (Turan, Selçuklular, S. 269).

103 Aksarâŷ̂, S. 286.

104. Aksarâyî, S. 70.

105 İbn Bîbî, Giyâsü'd-dîn Keyhusrev I. Bizans'da iken "saray-1 sultan"da ikamet ettiğini yazıyor (Lugal-Erzi, s. 113). Ancak onun annesinin Bizans sarayına mensub olduğu da bilinmektedir.

106 Aksarâyî S. 75,76 . 
vus buradan Kırım'a kaçmış ve orada kendisine tahsis edilen iktâ'da ${ }^{107}$ oturmuşdur ${ }^{108}$.

Diğer taraftan Kılı̨ Arslan IV. öldürülmeden evvel Pervâne Mu'in ü'd-dîn tarafindan tertip edilen toy'a iştirak etmiştir. Sultan "hargâh-ı işret'de, yani işret meclisinin yapıldığı çadırda şarap içmiş$\operatorname{tir}^{109}$. Yazarın verdiği malûmattan ileri gelen Selçuklu devlet adamlarının sultanın şerefine ziyafet verdiklerini görüyoruz ${ }^{110}$.

Müsâmeretü'l-Ahbâr'da sultanların yaptığı kabullere dair bilgi mahduddur. Kabul şekli ve merasim hakkında kayıt yoktur. Yalnız Kılıç Arsıan I.ın Abbâsî halifesinin elçisini kabul ettiğine dair kısa bir pasaj vardır ${ }^{111}$.

\section{Saray âdetleri}

Türkiye Selçuklu Devleti'nde saray âdetleri ve saray hayaínm Büyük Selçuklu İmparatorluğu devinin aynı olduğu muhakkakdır. Bu bakımdan geçmişe ve geleneklere bağlılık saray teşkilâtı ve hayatında geniş çapta kendini göstermiştir.

Eserde açıkca belirtildiği gibi, Büyük Selçuklu İmparatoru Melikşah ve diğer Selçuklu sultanları devrinde olduğu gibi "âyin-i saltanat" gereğince cuma günleri sarayda resm-i kabul yapılıyor ve devlet ricâline, kadılara ve bilginlere saray mutfağından ziyafet veriliyordu ${ }^{112}$.

\footnotetext{
107 Aksarâyî, S. 77 .

108 Izzü'd-dîn Keykâvus, memleketten kaçtıktan sonra 1262'de İstanbul'a ulaştı ve İmpa rator Michael Paleologos tarafindan gayet iyi karşılandı. Michael oun muhafizları ve maiyeti ile yaşamasına hükümdarlık elbise ve alâmetlerini taşımasına müsaade etti. Ancak Türk ümrerâsı Michael'i bertaraf ederek Bizans'ı Keykâvus'a mal etmek gibi cüretkâr bir plân hazırladılar. Sultanın hırıstiyan dayısı Kir Kedîd'in ihbar üzerine yalalandılar ve tevkif edildiler. Michael, sultam iki oğlu ve annesi ile beraber Trakya'da Inoz kalesie kapattı. 1264-65 kışında Altın Ordu kuvvetleri sultanı kurtarmış ve üç oğlu ve adamları ile beraber Ber ke han'a götürmüşlerdir, Berke, Kırım'daki Sağdak ve Sulhâd vilâyetlerini sultana iktâ olarak verdi. Keyhkâvus burada 1278'de vefat etti (Kaymaz, Pervâne, S. 224 ve dv).

109 Aksarâyî, S. 86.

110 Nesevî, Harzmşahlar'da, vezîrlerin sultanın huzurunda şarap içmediklerine işaret etmektedir (Histoire de sultan Djelal Ed-Din Manlobirti, Paris. 1895, S. 377).

111 Aksarâyî, S. 28 - 29.

112 AksarâyîS. 90. Turan, şâmâni Türk telâkkisinin bir devamı olan hükümdarın ziyafetler vermesi âdetinin, Dede Korkut'da açıkça görüldüğü gibi yalnız göçebelerde değil Karahanlılar'da ve Büyük Selçuklular'da da muhafaza edildiğine işaret ediyor. (a. g. e. S. 49 -50).
} 
Bu ziyafetlerde eski Türk adeti; (toy- hân-1 yağma) gereğince sofra davetliler tarafindan yağma ediliyordu ${ }^{113}$.

Sultanların çocukları hükümdarlı âyin ve merasimi (âyin-i hüsrevâne) göz önünde bulundurularak yetiștiriliyorlard ${ }^{114}$.

Eserde ölen sultanlar için yas tutulduğuna dair kayıtlar var ise de $^{115}$ fazla bilgi yoktur ${ }^{116}$. Aksarâŷ̂’nin Kılı̨̧ Arslan IV. ın katli münasebeti ile yazdığına göre sultanın naaşı Aksaray'dan Konya'ya, mıhaffe (tahtz-revân) ile nakledilmiștiri"16a.

Aksarayî̀de devrin, komşu veya vasal devletler ile akrabalık ilişkileri kurulması yolundaki teamülüne uygun olarak Selçuklu-İlhanlı hanedanları münasebetine dair pasajlar vardır. Bunlardan birincisinde Pervâne Mu'niü'd-dîn ve vezîr Fahrü'd-dîn Ali’nin

113 Kaymaz, Pervâne, S. 98. Sümer'e göre toylar doğum, beğ oğlunun ilk avı, bir dilekte bulunma, bir felâketten kurtulma yâni bir sevinç vestilesi ile verilirdi. Yalnız beylere değil halka da verilen toyların diğer Türk kavimlerinde olduğu gibi Oğuzlar'ın da sosyal hayatında önemli rolü vardı. Beylerbeği Salur Kazan Bey. Üs - Ok ve Boz - Ok beğleri obasına geldiklerinde, yılda bir defa onlar için büyük bir toy verirdi. Toydan sonra Kazan, hatunun elinden tutarak dışarı çıkar, davetliler toyun verildiği yerdeki bütün eşyayı yağmalarlardı. Bir boyun toplantılarda ve toylar'da oturacağı mevki (orun) ve yiyeceği et kısmı (ïlüş) yalnız Oğuz elinde değil, bütün Türk kavimlerinde kaidelere bağh idi. Bu geleneklerin, bir boyun kendi eli içindeki politik ve sosyal hukukunu tâyin eden müesseseler olması bakımından önemi vardır (Oğuzlar, S. 400-401, ve 206). İzzü'd-dîn Keykâvus I. in Mengücek oğlu Behram şah'in kızı ile nikâhlandığı sırada yapılan şenliklerde verdiği ziyafet, hân-ı yağma mahiyetini almış, dâvetliler kıymetli eşyayı yağmalamışlardır. (Turan, Keykavus, I-A), Șeylan-şölen hk. bk. Köprülü Edebiyat araştırmaları, s. 72 ve $\mathrm{dv}$.

114. Aksârayî S. 88 .

115 Aksarâyî, S. 29. 88,

116 İbn Bîbî, Giyâsü'd-dîn Keyhüsrev I. in kardeşi Süleyman-Şah II. in ölämünü haber alınca üç gün yas tuttuğunu yazıyor (Lugal - Erzi, S. 117); Alâü'd-dîn Keykûbad I. için de üç günlük matem merasimi (resm-i ezâ) yapıldı. Gıyâsü'd-dîn Keyhüsrev II. beyaz atlas giyerek tahta oturdu. Bütün emîrler ve hizmetkârlar elbiselerinin üzerine gâşiye'ler geçirdiler.Beşinci gün K ey kubâd'ın cenazesi Konya'ya getirildi.Aynı gün mateme son verilerek sultan tarafından devlet erkânına hil'at'ler giydillildi. Bunu müteakib sarayda büyük bir bezm kurularak yeni sultanın cülûs'u ilân edildi (Ka y maz, İdare Mekanizması, II. S. 33-34). Sümer, Oğuz Eli'nin başhica yas alâmetinin ak renkteki elbiselerini çkarıp karalar giymek olduğuna işaret ediyor. Bu gelenek Selçuklu devrinde Türkmenler arasında, Iran Moğolları'nda, Timurlular'da, Kara Koyunlular'da, Ak Koyunlular'da, Anadolu Beylikleri'nde ve Osmanl lar'da, vardı (Oğuzlar, S. 404). Bu. hususda bk. Köprülü, a. g. e. s. 97.

116 a Aksarayî, S. 87 . 
Kılı̨̧ Arsılan IV'in kızı Selçuk hatun ${ }^{117}$ u Abaka ile evlendirmek üzere Anadolu'dan hareketlerinden bahsedilmekte ${ }^{118}$ diğerlerinde $\mathrm{Ga}$ zan'ın şehzade Hulacu'nun kızını Alâü'd-dîn Keykûbad III. ile evlendirdiği kaydedilmektedir ${ }^{119}$.

Orta-Doğu'da câri devlet anlayışında "Hükümdarm bütün otoriteler, kanun ve nizamlar üstünde olan mutlak otoritesinin haksızlıkları bertaraf etmek için en son tedbir olması" prensibinin ${ }^{120}$ tatbikatına bilhassa Giyâsü'd-dîn Keyhûsrev III. devrinde rastliyoruz. Saray çavuşları, zulme uğrayan kimselerin "dergâh'ı saltanat"a baş vurabileceklerini ilân ediyorlardı. Buna rağmen şikâyetçi çıkmıyordu ${ }^{121}$. Gene bu devirde reây $\hat{a}^{\prime}$ nn huzur ve sükûn içindeki durumu da belirtilmektedir ${ }^{122}$. Bu suretle yazar, Moğol işgali altındaki Anadolu'da sultanın halkın üzerindeki zulmü gidermek, kuvvetlinin zayıfı ezmesine meydan vermemek, reâya'nın canını ve malını emniyet altına almaktaki rolünü belirtmekte, saray-reâya ilişkilerine dair bilgi vermiş olmaktadır.

Aksarâŷi, eserinin sonunda ise Alâü'd-dîn Keykûbad III.ın Harput, Malatya, Divriği, Sivas'ta yaptığı zulümleri kınamakta ve saltanat mefhumu ile bağdaştırmamaktadır ${ }^{123}$. O, Alâü'd-dîn'in Sivas'ta bulunduğu sırada kadir gecesine tekaddüm eden günde çevgân oynamasını, at sürmesini, ramazanda oruç yemesini, işret âlemleri tertib etmesini de hoş karşılamıyor ${ }^{124}$.

$\mathrm{Bu}$ derece ileri gitmemek ile beraber diğer Selçuklu sultanlarının da dinî taassubdan uzak olduklarını, serbest hareketler yaptıklarını zaman zaman devlet ve ilim adamlarının tenkidlerine uğradıkların, fakat hiç değil ise zevâhiri kurtardıkları malûmdur ${ }^{125}$. Bununla beraber

117 Reşidü'd-dîn, Selęuk Hatun'u Argun Han'ın karılarından biri olarak gösterir (Selçuk hatun için bk. Kaymaz, Pervâve, S. 246).

118 Aksârâyî, S. 100.

119 Aksarâyî, S. 279.

120 H. Inalcık, Adâletnâmeler, Türk Tarih Belgeleri Dergisi, II. (1965). S. 49.

121 Aksarâyî, s. 89.

122 Aksarâyî, S. 98.

123 Aksarâyî, S. 282.

124 Aksarâyî, S. $282-283$.

125 Meselâ Süleyman-Şah II için İ̉n Bîbî, içki meclisleri kurduğunu, bununla beraber üç aylarda ve haftanın pazartesi ve perşembe günleri oruç tutacak kadar dindar olduğunu rivayet eder (Turan, Süleyman şah II, IA). Diğer taraftan kadı Tırmizî, Gıyâsü'd -dîn Keyhüsrev I. in gurbette şer'iata aykırı hayat sürdüğü için sultan olamıyacağına 
gayet tabii olarak eğitim gördükleri surada sultanlara dinî terbiyede veriliyordu. Meselâ çocuk iken tahta çıkan Gıyâsü’d-dîn Keyhüsrev III. i öğretmeni oruç tutmağa ve namaz kılmağa teşvik etti. ${ }^{125 a}$.

Eserde Selçuklu sultanlarının devlet erkânına hitab tarzları hakkında bir pasaj da vardır. Kılı̨̧ Arslan IV. Pervâne Mu'inü'ddîn'e ici (ağabey) şeklinde hitab ediyordu ${ }^{126}$. Genel olarak, sultanlarnn bu şekilde hitabettikleri bilinmektedir ${ }^{127}$.

Taht mücadelelerinde, "ülke hanedan üyelerinin ortak malıdır" prensibinden, iktidarı ele geçirenin, mücadeleyi kaydedenlerin kaderini tayin edebilmesinin örneklerine rastlıyoruz. Müşterek saltanat süren İzzü'd-dîn Keykâvus II., Kılı̨̣ Arslan IV. ve Alâü'd-dîn Keykûbad II. den ilk ikisi üçüncü kardeşlerinin lalası Muslih'i elde etmişler ve onu zehirleterek öldürtmüşlerdir ${ }^{128}$. Selçuklu sultanlarının kardeşlerini veya oğullarını katlettirme cihetine gitmeyip -devrin anlayışına göre merhametli davranarak- onları habsettirmek ile iktifa ettiklerini gösteren örnekler de vardır. Gerçekden Gıyâsü'ddîn Keyhusrev J.kardeşi Süleyman-şah II.ın oğlu İzzü'd-dîn'i' ${ }^{129}$; İzzü'd-dîn Keykâvus I. kardeşi Alâü'd-dîn Keykûbad'1 ${ }^{130}$; İzzü'd-dîn Keykâvus II de kardeşi Kılı̨ Arslan'1 ${ }^{131}$ hapsettirmişlerdir.

Ancak bu olaylarda, siyasî hesapların ve çeşitli kliklere mensup devlet adamlarının etkisinin olduğu muhakkakdır ${ }^{132}$.

dair fetva vermişdir. Gıyâsü'd-dîn tahta geçince kadıyı idam ettirdi. (Turan, Gıyâsü'd-din Keyhüsrev I., IA). Keyhüsrev II. ise karısı olan Gürcistan kralicesi Rusudan'ın kızının sarayda, memleketinden getirdiği papazlara, dinî tasvirlere, hurıstiyan maiyetine ve özel kilisesi olmasına müsaade etmiştir. Selçuklu sarayında bu gibi olaylar münferit değildi (Turan, Keyhüsrev II., IA).

125a) Aksarâyî, S. 88 .

126 Aksarâyî, S. 85 . Ici için bk. a. g. e. S. 85 not: 5 .

127 Hârizmşahlar'da sultanlar vezîrlerine -genel olarak- hace unvanı ile hitab ederlerdi (Nesevî, a. g. e., S. 172), Arab. met., S. 104; farsç. terc. S. 136.

128 A ksarâyî, S. 39. Bu olay hakkında kaynakların mütenakız ifadeleri için bk. Kaymaz, Pervâne. S. 185 - 186.

129 Aksarâyî, S. 32 .

130 Aksarâyî, S. 33

131 Aksarâyî, 2 S. 4.0.

132 Fazla bilgi için bk. Turan, IA ilgili maddeler. 


\section{B. HÜKÜMET TEŞKILLATI}

Aksarâŷ̂̀nin eserinde Selçuklu hükûmeti teşkilâtına dair oldukça geniş malûmat vardır. Başta vezir olmak üzere nâib-i sultan, at abey, pervâne, müşrif, müstevfî̀v.b.nin görev ve yetkilerine ait bilgiler bu cümledendir. Ancak yazarın verdiği malûmat Anadolu'nun Moğol tâbiiyeti ve işgali altında bulunduğu devre ait olduğundan Selçuklu devlet adamlarının görev ve yetkileri "daimî Moğol müdahalesi ve baskısı" faktörü gözönünde bulundurularak değerlendirilmelidir. Bu bakımdan Aksarâyî'nin eserinde bu bahse taallûk eden konular, Türkiye Selçuklular'ı hükûmet teşkilâtının işleyişi hakkında açı bir fikir vermez. Bu durum, devlet mekanizmasındaki vazifelilerin normal görev ve yetkilerini etkilediği gibi, onların sadece, gerçek iktidar sahibi metbûun emirlerini icraya memur birer vasıta oldukları hakikatinide ortaya koyar.

Kuruluş, yükseliş ve duraklama devirlerinde -çă̆daşı diğer bütün siyasî teşekküller gibi - Türkiye Selçukluları Devleti’nde de iktidarın tek mutlak hâkimi hükümdardı. Saray, hükûmet, ordu ve adalet teşkilâtı mensubları da derece derece kanunların ve geleneğin kendilerine bahşettiği haklar nisbetinde söz sahibiydiler.

Moğol tahakkümü altındaki Türkiye Selçuklu Devleti'nde ise sultanlar zaman zaman atabey, vezir, nâib-i sultan ve pervâne'lik makamlarını işgal eden kimselerin elinde kukla vaziyetinde kalmışlardır. Bu durumda Selçuklu Devleti'nde iktidarın gerçek sahibi, ancak İlhanlı hükümdarına ve devlet erkânına hesab vermek zorunda olan hükûmet mensublarından biri olmuştur.

Devlet mansıbları sultanların tahta geçişleri veya saltanatlarının İlhan tarafindan ibka edilmeleri halinde yeniden tevcih ediliyordu. Saltanat makamının ihraz ettiği yeni hüviyetin icabı olarak başta vazâret olmak üzere yüksek makamlara yeni tâyinler yapılıyordu ${ }^{133}$. Bunun sebebi, evvelki hükümdar devrindeki hukukî tasarrufların geçerli olmadığı prensibidir.

Bu devrin şartlarının yarattığı bir durum da, hükümet teşkilâtında yüksek seviyedeki kadroların zaman zaman İlhanlı kadrolan ile birleştirilmesidir. Bu vaziyette iki görev ilhan tarafından bir şahsın

133 Meselâ, S. 133'de manbsıblara yapılan yeni tâyinler vardır. 
uhdesine verilmiştir. Bu da şüphesiz bürokraside koordinasyonu temin etmek içindir.

Diğer tarafdan başta sultan olmak üzere bütün devlet erkânı Meclis- $i$ Yargu'da mahkeme edilebiliyorlardı.

Aksarâŷ̂̀nin üzerinde durduğu hususlardan biri de devletin ikinci derece memurlarının yetersizliğidir ${ }^{134}$. Bu suretle yazar hükümet mekanizmasının aksaması nedenlerinden birini de izah etmiş olmaktadır ${ }^{135}$.

Son olarak şuna da işaret edelim ki, bu devirde mansıbların taşıdıkları isimler daha evvelki devirlerdeki memuriyet isimlerinden farklı değildir.

\section{Büyük Divân}

Büyük Divân devlet idaresinin en yüksek organı olup, devlet işlerinin görüşüldüğü ve karara bağlandığı kuruldur. Vezir'in başkanlığındaki Büyük Divân'ın üyeleri, nâib-i sultan, atabey, pervâne, müstevfi, tuğrâ̂, emir-i ârız, emir-i dâd ve müşrif-i memâlik'tir ${ }^{136}$.

Müsâmeretü'l-Ahbâr'da, Büyük Divân'in üyeleri, toplantıları, çalışma tarzı hakkında hemen hiç bilgi yoktur. Yalnız Alâü'd-dîn Keykûbad III. devrinde Yabanlu yaylağı'nda yapılan bir divan toplantısı hakkında kayıt vardır. Moğol kumandanı Abuşka'nın nezaretindeki toplantı "Hayme-i Divan"da yapıldı. Hattâ Abuşga divân üyelerinden birini, toplantıya geç kaldığını bahane ederek işkence ile öldürttü ${ }^{137}$.

\section{Divân Üyeleri ve divanlar}

Vezir: Hükûmet teşkilâtının başıdır. Türkiye Selçuklu Devleti vezîrleri Büyük Selçuklu İmparatorluğu'nda aynı makamı işgal eden meslekdaşları gibi, -genel olarak- "ehli kalem"den, yani sivil teşkilât kadrosundandırlar. Ancak Pervâne Muinü'd-dîn ve Fahrü'd-dîn

134 Aksarâyî, S. 143

135 İbn Bîb̂̂'de Alaü'd-dînKaykubad'I. devrinde divan muamelatının iki tercüman man ve dört münşî ile idare edildiği Moğol tabiyeti devrinde ise on misli bir kadronun mevcut olduğu ve ehliyetsiz memurlarm dolgun ücret aldıkları yozılır (Kay maz Pervâne, S. 185)

136 Kaymaz, Pervâne, 193. Uzunçarlı̧̧ı bu kadroya emir-i dâd'r koymamışdır. (Medhal, S. 97). Protokol için bk. El-Hoy î, Gunyetü'l-Kâtib (nşr. A. S. Erzi, Ankara, 1963).

137 Aksarâyî, S. 286 - 287. 
Ali ile ilk defa olarak “ehli seyf'den, yâni askerî kadrodan vezîrler işbaşına geldiler ${ }^{137 a}$.

Vezirlerin daha evvel işgal ettikleri makamlar: Aks ar ây î'nin bahsettiği ilk vezîr İzzü'd-dîn Keykâvus II. devrinin vezîrı İzzü'd-dîn'dir. Aksarâyî onun mesleğinin kadı olduğuna işaret ile yetinmişdir ${ }^{138}$.

İzzü'd-dîn'den sonra vezarete Şemsü'd-dîn Mahmud getirildi. Bu zatın daha evvelki görevi tuğrâ̂’’lik idi ${ }^{139}$.

Kısa bir inkita devri dışında uzun yıllar vezarette bulunan Fah r ü 'd dîn Ali ise, bu makama nihyâbet-i saltanat'tan getirildi ${ }^{140}$.

Fahrü'd-dîn Ali'nin bir müddet için vezirlikten uzaklaştırıldığı surada müstevfî Mecdü'd-dîn Mehmed vezarete tâyin edildi. ${ }^{141}$

Alâü'd-dîn Keykubad III. in veziri Alâü'd-dîn S âvî̀nin ise ${ }^{142}$ evvelki görevi tasrih edilmemiştir.

Vezîrin tâyin şekli : A ks a ra y înin İ z z ü'd - dîn K e y kavus I I.ın ilk defa vezarete kadı İ z z ü' d - d în 'i, kardeşlerini ekarte ettikden sonra tâyin ettiği şeklinde kaydı doğru değildir. Kadı İz z ü 'd dîn bu makama daha evvel üç kardeşin saltanatı zamanında atabek- $i$ Rûm Celâlü'd-dîn K a ratay tarafindan tâyin edildi ${ }^{143}$.

Gene İzzü'd-dîn Keykâvus II.ın vezîrlerinden Şemsü'd-dîn Mahmud ise bu memuriyete ilhan tarafından çıkarılan yarlık ile tâyin edildi $^{144}$.

137 a Turan da, bazı istisnalar dışında teamüle göre vezirlerin ilmiyye mesleğine mensup olduklarına işaret etmiştir. (Celâleddin Karatay, S. 35).

138 Aksarâyî, S. 40. Kadı İzü'd-dîn vezâretinden evvel müşrif, Konya kadılı̆̆ $\imath$ ve ataatabey'lik görevlerinde bulundu (Kaymaz, Pervâne, S. 191).

139 Aksarâyî, S. 63.

140 Aksarâyî. S. 63. Fahrü'd-dîn Ali'nin vezareti sırasında bir ara Pervâne Mu'inü'd-dîn de, Hulagu'nun yarlığı ile Kılıç Arslan IV'e vezîr oldu (Kaymaz, Pervâne, S. 55).

\footnotetext{
141 Aksarâyî, S. 93.
}

142 Aksarâŷ̂, S. 285. ve dv.

143 Aksarâyî kadı İzzü'd-dîn'in selefi Necmü'd-dîn Nahcevânî'den bahsetmemiştir. Bu zat Karatay tarafından üç kardeşin saltanatınun başında vezîrliğe tayin edildi. (Kaymaz, Pervâne s. 24). Şemsü'd-dîn Mahmud'un Karatay tarafindan azlinden sonra, gene Karatay vezârete tekrar kadı İzzü'd-dîn'i getirdi (Bilgi için bk. Turan, Karatay, S. 39.)

144 Aksarâyî, S. 63 . 
Fahrü'd-dîn Ali'nin ise yarlık ile tâyin edildiğine dair eserde kayıt yoktur ${ }^{145}$. Bu tâyinin İzzü'd-dîn Keykâvus II. tarafindan metbûuna danışılmadan yapıldığı anlaşılmaktadır ${ }^{146}$.

Fahrü'd-dîn Ali'nin azl ve haps edilmesini takiben vezârete getirilen Mecdü'd-dîn Mehmed'in tâyin şekli hakkında eserde vuzuh yoktur ${ }^{147}$. Mecdü'd-dîn Mehmet'i bu makama o sirada çok nufuzlu olan Pervâne Muinü'dîn Süleyman getirdi' ${ }^{148}$. Ancak Fahrü'ddîn Ali'nin Moğollar tarafından yarguya çekildiği ve Muinü'd-dîn'in de onların sözünden çıkamadığı gözönünde bulundurulur ise, Me c dü'ddîn bu makama herhalde Anadolu'daki Moğol noyanlarının tasvibi ile tâyin edilmiştir.

Fahrü'd-dîn Ali'nin vezîrliğe ikinci defa tâyini İlhan Abaka'nın yarlığı ile mümkün olmuştur ${ }^{149}$.

Vezîr Alâü'd-dîn Sâvî ise ${ }^{150}$ her halde yarlık ile tâyin edildi.

Vezirlerin görev ve yetkileri: Aksarâyî, Selçuklu vezîrlerinin teşriî, icraî, kazaî ve askerî yetkilerine dair tatminkâr bilgi vermemiştir. Esasen yazar devlet adamlarının idare mekanizmasındaki rolünü, görev ve yetki bakımından belirtmek yerine, nufuz ve hâkimiyet cihetinden değerlendirmek yolunu ihtiyar etmişdir.

Vezîr Şemsü'd-dîn Mahmud'un nufuzlu olduğundan bahsetmesi' ${ }^{151}$, Fahrü'd-dîn Ali'nin, Pervâne Mu'inü'd-dîn ile iyi geçinmek zorunda olduğunu belirtmesi ${ }^{152}$, iktidarın vezîr Fahrü'd-dîn Ali ile nâib-i sultan Mucirü'd-dîn Emîrşah elinde olduğu ${ }^{153}$ nu yazması bunun açık delilleridir.

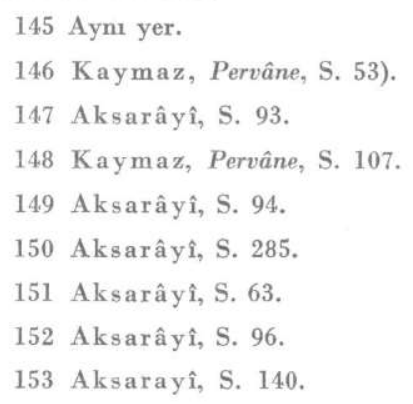


Buna mukabil vezîrin icraî yetkileri meyanında Şemsü'd-dîn Mahmud'un uzak vilâyetlerdeki serleşker ve nâiblerden sultanın sarayındaki hizmetkârlara (hadem ve havâşî) kadar bütün görevlilerin hiç biri onun emri olmaksızın hiç bir şeye tasarruf edememeleri ${ }^{154}$ ve fermanlar ve menşurlar (menâş̧ir-i divâniye) de yalnız Fahrü-d-dîn Ali'nin alameti olması ${ }^{155}$ gibi kayıtlar vardır.

Askerî görev ve yetkileri meyanında orduya komuta etmek de vardı. Kadı İzzü'd-dîn'in -sultan İzzü'd-dîn Keykâvus II.ı Moğollar ile savaşa teşvik ettikden sonra Aksaray yakınında Sultanhanı civarındaki savaşa katıldığı, fakat şehid olduğu ${ }^{156}$, F ahrü'd-dîn Ali'nin Gıyâsü'd-dîn Keyhüsrev III. ile beraber Cimri için yapılan harekâta iştirak ettiği $i^{157}$, Alâü'd-dîn Sâvî’nin Moğol kumandanı Abuşka ve sultan Giyâsü'd-dîn MesudII. ile beraber Niğde-Aksaray arasındaki bir kaleyi muhasara ettikleri ${ }^{158}$ yazılıdır. Esasen "mühür-ü vezâret ve emâret" ibaresi ${ }^{159}$ vezir'in mülkî yetkilerine ilâveten askerî yetkilerinin de bulunduğuna işarettir.

Protokol bakımmdan vezir: Vezîrlik makamının sembolü olarak altın divit ${ }^{160}$ ve mühür-ü vezâret ve emâret ${ }^{161}$ zikredilmektedir $^{162}$. Bu arada İzzü'd-dîn Keykâvus II.ın Fahrü'd-dîn Ali'ye hil'at-t fâhir gönderdiği de zikredilmiştir ${ }^{163}$. Vezîrin diğer sembolleri olan $k a$ lensöve, dest (minder) ve tuğ’a dair bilgi yoktur. Vezîrin makamı veya evi için dergâh $h^{164}$ tâbiri kullanılmıştır.

Vezirin tahsisatı: Selçuklu Devri Türk Devletleri’nde vezîrin; 1-Maaş ve masraf tazminatı; 2-Bütün iktâlardan ve sultana ait hass'lardan aldığı âşar; 3-Res'en verilen iktânın geliri olmak üzere başlıca üç gelir kaynağı

154. Aksarayî, S. 62 .

155 Aksarâyî, S. 63 ve 146 .

156 Aksarâyî, S. $41-42$.

157 Aksarâyî, S. 130.

158 Aksarâyî, S. 295.

159 Aksarayî, S. 94. Gıyâsü'd-dîn Keyhusrev II. in vezîri Şemsü'd-dîn'e murassa kınh kılıç göndermesi vezîrin askerî yetkilerinin olduğuna delâlettir (Ka y maz, Idare Mekanizması, I. S. 11).

160 Aksarâyî, S. 63.

161 Aksarâyî, S. 94 .

162 Giyasü'd-dîn Keyhüsrev II vezirine altın kalem de göndermişdir.

163 Aksarâyî, S. 63 .

164 Aksarâyî, S. 64 . 
vardır. Müsâmeretü'l-Ahbâr'da vezîrin yalnız kendi iktâından bahis vardır $^{165}$. Vezîr Şemsü'd-dîn Mahmud'a Kastamonu vilâyeti'nin gelirleri "maişet-i vezâret" olarak verilmiştir ${ }^{166}$.

Vezirin azli: Sahib Fahrü'd-dîn Ali, vaktiyle sultan İzzü'd-dîn'in Kırım'dan gönderdiği bir mektub vesilesiyle ona değerli hediyeler ve bu arada bir altın maşrapa gönderdiği bahane edilerek azledildi. Pervâne Mu'inü'd-dîn tarafdarları Moğol kumandanlan ile işbirliği yaparak onu “mesned-i vezâret”den düşürdüler. Fahrü'd-dîn Ali yarguya çekildi ve hapsedildi ${ }^{167}$. Daha sonra Fahrüd-dîn Ali eski görevine iade edildi. Böylece açıkta kalan Mecdü’d-dîn Mehmed vezâretten atabeyliğe tâyin edildi ${ }^{168}$, ve görünüșe göre ona "atabek-i Rûm” unvanı verildi. Sahib Alâü'd-dîn Sâvî̀' ise, Selçuklu Devleti'nin tarihe karışmak üzere olduğu surada vezîrlikten, Moğol kumandanı Abuşga'nın maiyetine girmiş ve uluğ bitikçi ${ }^{169}$ olmuştur ${ }^{170}$.

Nâib-i sultan: Varlığını Selçuklu Devletleri’nden yalnız Türkiye Selçukluları'nda gördüğümüz ${ }^{171}$ nâib-i sultan ${ }^{172}$ vezîrden sonra hükûmette en önemli makamı işgal ediyor idi. Aksarayînnin bu mansıba yapılan tâyine dair ilk kaydı,emir-i dâd Fahrü'd-dîn Ali'nin, niyâbet-i saltanat'a getirilmesidir ${ }^{173}$. Daha sonra müstevfî Emin ü'd-dîn Mikâil

165 Necmü'd-dîn Nahcivanî vezîrliği kabul etmek için kendisine yılda 720 dirhem tahsisat verilmesini, ümerânın da maaşlarının buna göre ayarlanması şartını ileri sürdü. Karat a y, ümerânın buna razı olmayacağın bildiğinden, N e cmü'd-dîn'e eski vezirlerin en iyi ve en kanaatkânndan Mühezzabü'd-dîn Ali'nin aldığı vıllık 40000 dirhem tahsisatı kabul ettirmiş, emîrleri de eski aldıklarının yarısına razı etmiştir (K a y maz, Pervâne, S. 181).

166 Aksarâyî, S. 63. bu vezîre Giyâsü'd-dîn Keyhüsrev II. Kırşehir'in iktâ ve serkeşkerlik menşuurunu da verdi (Kay maz, Pervâne, S. 170).

167 Aksarâyî, S. $92-93$.

168 Aksarâŷ̂, S. 95 .

169 Görünüşe göre Çinliler'den Karahanlılar'a geçen bitikçi, o devirde hükümdarın yazı işlerini idare eden, devlet esrarına vakıf olan ve vezîr ile aynı önemde yüksek bir memurdu. Türkler'den Moğollar'a geçen bitikçi, Ilhanlılar'ın büyük divânında divandan çıkacak emir ve kararları yazdırır ve divana ait malî işlere bakardı. Eyalet divanlarındaki bitikçi'leri uluğ bitikçi seçerdi (M. Mansuroğlu, Bitikçi, IA) Ayrıca Bk. B. Spuler, Iran Moğolları, Ankara, 1957. S. $341,346,365,444)$.

170 Aksarâyî, S. 291.

171 Mısır'daki Kölemenler Devleti'nde gördüğümüz nâib-i sultan için bk. Uzunçarşılı, Medhal, S. 417 ve dv.

172 Oğuz Yabgu Devleti'nde yüksek bir memur olan Kül-erkin yabgu'nun nâibi veya vekili demektir. Bu tâbirin Türkiye'ye geldiğine dair delil yoktur. Ancak nâib-i sultan'm menşei bu memuriyet olabilir (Sümer, Oğuzlar, S. 52).

173 Aksarâyî, S. 61. 
bu makama tâyin edildi ${ }^{174}$. Niyâbet-i saltanat makamında uzun yıllar bulunan Mücîrü'd-dîn Emîrşah ise, İlhanlılar'in Anadoludaki gelirlerini kontrol eden vezîr unvanlı yüksek memur olan Tacü'd-dîn Mûe tez ${ }^{175}$ in halefi ve oğludur ${ }^{176}$. Emîrşah'in tâyini, Selçuklular'daki büyük makamlara İlhanlı devlet adamlarının resmen getirilmeleri bakımından önem taşımaktadır.

Niyâbet-i saltanat makamında kısa bir müddet bulunan K emâlü'ddîn Tiflisî ${ }^{177}$ nin ise, bu makama hangi görevden tâyin edildiği hakkında bir kayıt yoktur.

Fahrü'd-dîn Ali, Nâib-i sultan'lğa İzzü'd-dîn Keykâvus II. tarafından tâyin edildi ${ }^{178}$. Kaynağımızda Moğollar'ın resen tâyin veya etki yaptıklarına dair bir bilgi yoktur. Gene Fahrü'd-dîn Ali'den boşalan bu makama getirilen Eminü'd-dîn Mikâil'in tâyin ${ }^{179}$ şekli vâzıh değildir. Ancak bu devirde Selçuklu devlet adamlarının metbû devlet nezdinde münferit teşebbüsler yaptıklarını ve emri vâki yaparak kendileri için tâyin yarlıkları temin ettikleri nazarı itibare alınmalıdır.

Mucirü'd-dîn Emîrşah ise bu makama Gıyâsü'd-dîn Mesud II. tarafindan tâyin edildi. Sultan bu tâyine ait menşuru tasdik etmesi için ilhana arzetti ${ }^{180}$. Emîrşah daha evvel babası Tâcü'ddîn Mu'tez'in yerine Abaka tarafindan tâyin edilmişti ve Anadolu'da vazifedeydi $^{181}$. Böylece o hem Ilhanl, hem de Selçuklu memuriyetini işgal etmiş oldu.

Niyâbet-i saltanat makamını işgal eden zatın tâyini -diğer bütün yüksek makamlar gibi- İlhanlı veya Selçuklu tahtlarında vâkî değişikliklerde ve hattâ görünüşe göre, ilhanın Anadolu'ya gelişi münasebeti ile tecdit ediliyordu ${ }^{182}$.

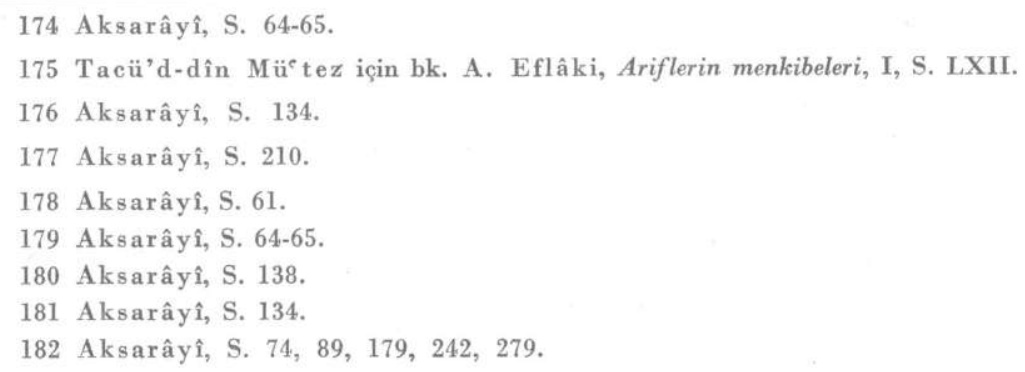


Nâib-i sultan geniş yetkiler ile mücehhezdi. Hükümdarın gaybubetinde devlet işlerinin idaresini deruhte eden ${ }^{183}$ niyâbet-i saltanat makamını işgal eden kişilerin nufuzlu olacakları ${ }^{184}$ tabiidir. Özellikle Anadolu'nun malî bakımdan ikiye taksiminde Dânișmendiye vilâyeti ${ }^{185}$ nin idaresini üzerine alan Emirşah'ın (diğer kısım Fahrü'üddîn Kazvinî’ye verilmiş idi) icraî yetkilerinin geniş olduğu görülmektedir $^{186}$.

Nâib-i sultan askerî harekâta bilfiil katıllyor ve gerektiği zaman orduya kumanda ediyor idi: Eminü'd-dîn Mikâil, şehzade Konkurtay ve noyanlar'in lüzum göstermeleri üzerine Karamanoğulları isyanını bastırmak için harekete geçmiş ise de, başaramamıştır ${ }^{187}$. Gene Mikâil, Cimri isyanını basrıtmak için de faaliyet göstermiş, fakat netice alamamışıิr ${ }^{188}$. Emîrşah ise, Mesud II.un, isyan eden kardeşi Kılı̨ Arslan üzerine yaptığı sefere katıldığı ${ }^{189}$ gibi, ayaklanan Luluve kalesi kumandanı Sâbıkü'd-dîn'in itaatini sağlamıştır ${ }^{190}$. Gene Emîrşah, Niğde-Sivas civarlarında eşkiyalık yapan Bedrü'ddîn Veled'i de tenkil etmiştir. Emîrşah, Aksaray imam ve şeyhlerine, Bedrü'd-dîn'e teslim olduğu takdirde affedileceği yolunda bir teklif yapacağını, fakat yemininde durmayarak onu öldüreceğini söyledi; günaha girip girmeyeceğini sordu. Onlar bir hüccet ile mahzur olmadığı cevabını verdiler. Kendilerine bir de iktâ vaadedilen Bedrü'd-dîn ve adamları teslim olunca öldürüldüler ${ }^{191}$. Bunu müteakib Emîrşah asayişi temin etmek için Samsun'a gitti ${ }^{192}$.

Nâib-i sultan görev ve yetkilerinden Moğollar'a karşı sorumlu idi ${ }^{193}$. Gerçekten Emirşah hakkında bir kaç defa soruşturma açıl-

183 Aksarâyî, S. 61. Nâib-i sultan'm alâmeti altın kılıç idi (İbn Bîbî, tupkn basım, S. 540.)

184 Aksarâyî, S. 97 ve 156 .

185 Dânişmendiye ve Karaman cyaletleri için bk. Akdağ, Türkiye'nin iktisadi ve içtimai tarihi, S. 71-75.
186 Aksarâyi, 154 .
187 Aksarâyî, S. 112.
188 Aksarâyî, S. 124 .
189 Aksarâyî, S. 171 .
190 Aksarâyî, S. 254.
191 Aksarâyî, S. 254-255.
192 Aksarâyî, S. 256.
193 Aksarâyî, S. 158 . 
mışdır. Bazan İlhanlı şehzadelerinin ${ }^{194}$, bazan vezîrlerinin ${ }^{195}$ lüzum gösterdikleri sorgular meclis-i yargu da yapilıyor idi.

Nâib-i sultan protokolun kendisine tahmil ettiği icabları da yerine getiriyordu. Emîrşah, Mesud II.un refaketinde, ilhan Keygatu'yu uğurlamak için Aladağ yaylağı'na kadar gitmiştir ${ }^{196}$.

Makam mahalli dergâh $h^{197}$ olan nâib-i sultan'ın maiyetinde nuvvâb (nâibler) ${ }^{198}$, havâş̂̀ ve hadem ${ }^{199}$ vardı. Aksarâyî, onun maiyetindeki yüksek memurlar için musahib ${ }^{200}$ tâbirini kullanmıştır. Emîrşah'a muavin olarak, kardeşi Rüknü'd-dîn Mehmed de yardım ediyordu ${ }^{201}$.

Nâib-i sultan'ın gelir kaynaklarını, maaşının miktarını bilmiyoruz. Ancak geniş iktâları olduğu ve bunların, gelirinin büyük kısmını teşkil ettiği muhakkakdır.

Niyâbet-i saltanat makamını işgal edenler Moğollar tarafından azledilebiliyorlardı. Mucirü'd-dîn Emîrşah ise onlar tarafından öldürülmüşdür ${ }^{202}$.

Atabey: Müsâmeretü'l-Ahbâr'daki bilgilerden atabeylik hakkında bilgi edinilememektedir ${ }^{203}$. Atabey'in görevi hakkında en önemli kayıt O. Turan tarafından neşredilen Takarirï'l-manasib'da atabeylik tâyinine dair fermandır. Buradaki "Bütün devlet erkânı ile saltanat divanı nâiblerinin bütün işlerde atabeyin ittifak ve meşvereti ile hareket etmeleri" ibaresi ${ }^{204}$ atabey'in idareciler kadrosu içindeki önemli fonksiyonunu belirtmektedir.

F. Köprülï de Moğol işgali devrinde Türkiye Selçuklu Devleti'nde bu görevin ve unvanın varhğını belirtmiş ve zaman zaman merkezî

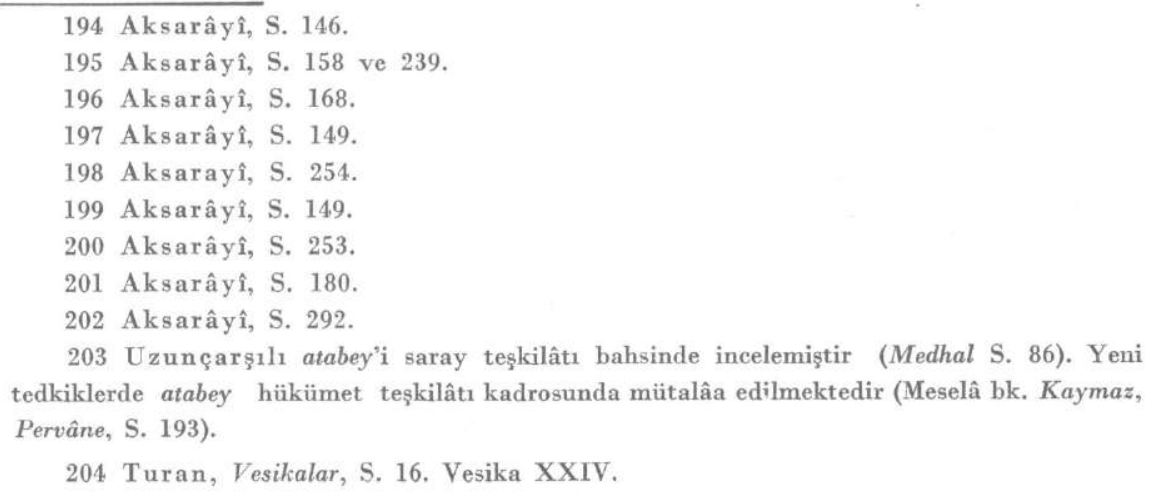


idarenin başındaki en yüksek âmire atabek-i azam lakabı verildiğine işaret etmişdir. Gene Köprülü, Türkiye Selçuklu Devleti'nde vilâyetlerin idaresine memur edilen şehzadelerin yanma büyük emîrlerden birinin, sultan tarafından atabey olarak tâyin edildiğini yazmıştır ${ }^{205}$. Aksarâyi-F. Köprülü’nün kasdettiği anlamda lala tâbirini kullanmış$\operatorname{tir}^{206}$.

Eserde, Celâlü'd-dîn Karatay'dan atabey olarak bahsedilmiş ${ }^{207}$, iktidarm tek sahibi olduğu devirde ise "hâkim-i memleket" olarak zikredilmiştir ${ }^{208}$. Eserde, Selçuklu kaynaklarındaki atabek-i R̂̂m ${ }^{209}$ tâbiri yoktur.

Atabeylik makamina sivil veya askerî ricalden kimseler tâyin ediliyordu. Eserde bahsedilen Karatay, Mübarüzi’d-dîn Erto$\mathrm{kuş}^{210}$, Arslan doğmuşs11 ordu kadrosundandırlar. Müstevfîlikten vezirliğe, vezîrlikten atabeyliğe tâyin edilen Mecdü'd-dîn $M e h$ med $^{212}$ her halde sivil teşkilât mensubu idi. Son devirdeki atabeylerden Mecdü'd-dîn'in aslî görevi kadılık idi ${ }^{213}$.

Bazı atabeylerin sultan üzerinde büyük nufuz sahibi oldukları görülmektedir. Alâü'd - dîn Keykûbad III.ün atabeyi Karahisarîn $\hat{i n}^{214}$ bu cümledendir ${ }^{215}$.

Pervâne: Eserde pervânelik (pervânegî) mansıbı hakkında tatminkâr bilgi yoktur; Selçuklu kaynaklarında da bu makamun mahiyeti hakkında malûmat azdır. Anlaşıldığına göre divân-ı pervânegî, başında bulunan pervâne'nin nezâreti altında mülk, iktâ ve sair arazi meseleleri ile uğraşmakta, bunlarla ilgili tâyin, tevcih, tahsis işlemlerini yapmakta, menşur ve beratları hazırlamakta ve defterleri tutmaktadır. Protokolda pervâne'nin yeri -görünüşe göre- vezir, nâib-i sultan, atabey ve beylerbeyi'nden sonra geliyordu ${ }^{216}$.

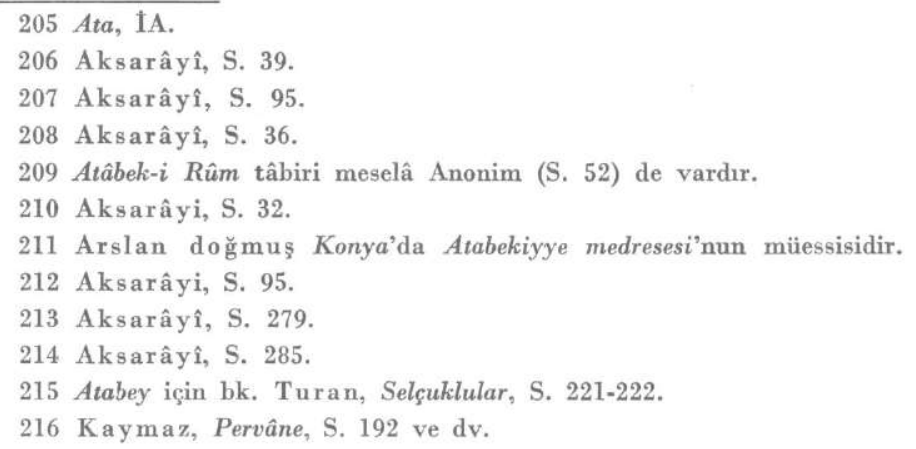


Aksarâyi’nin konusunu teşkil eden devirde pervânelik mansıbı hemen tamamen Mu'inü'd-dîn Süleyman ve oğullarında kalmıștır. Pervâne Nizâmü'd-dîn Hurşid ${ }^{217}$ den sonra 1266 yılında ${ }^{218}$ bu makama getirilen Mu'inü'd-dîn ${ }^{219}$ Türkiye Selçuklu Devleti tarihinde "Pervâne devri" ${ }^{220}$ olarak adlandırılan devrin yaratıcısı olmuş, iktidarın gerçek hâkimi olarak devleti idare etmiştir ${ }^{221}$.

Pervânelik makamina genel olarak ordudan yetişen ve emîr rütbesini alan şahıslar getiriliyordu. Mu'inü'd-dîn, emir-i hâciblik'ten bu makama geldi ${ }^{222}$. Aksarâyî, onun selefi Nizâmü'd-dîn Hurşid'den "sâhib-i kalem" olarak bahsediyor ise $\mathrm{de}^{223}$, bu, onun ehli kalemden olduğu manasına gelmez. Zira Hurşîd de ümerâdandır. Esasen kaynağımızda pervânegî̀nin emâret deyimi ile beraber kullanılması ${ }^{224}$ bu mansıbın askerî karakterinin ağır bastığını göstermesi bakımından önemlidir.

Pervâne'nin maiyetinde, onun nâibliğini ve hâcibliğini (niyâbet ve hicâbet) yapan görevliler vardı ${ }^{225}$. Nihayet Aksarâŷ̂̀'de pervâne Mu'inü'd-dîn Mehmed ve pervâne Rüknü'd-dîn'in kendilerine tahsis edilen mıntıkalarda ikâ ettikleri zulumun tafsilatı vardır ${ }^{226}$.

Müstevfî: Devletin malî işlerini tanzim eden istifa müessesesinin başında müstevfî vardır. Müstevfîlerin görev ve yetkilerine ait bilgileri Aksarâŷ̂'nin de bahsettiği Mecdü'd-dîn Mehmed'in, Takarirï'l-Manasıb'daki müstevfîlik menşurlarından öğreniyoruz. 0 nun başlıca görevi Selçuklu ülkesinin gelirlerini tesbit etmektir. Devlet erkânına, müstevfî’yi müstakil olarak tanımaları ve memleket gelirlerinin hesaplanmasında ona ve yardımcılarına müracaat edilmesi

217 Aksarâyî, S. 41.

218 Aksarâyî, S. 45 .

219 Aym yer.

220 Kaynaklardaki "Mu'inü'd-dîn Süleyman devri" adını araştırıcılarda benimsemișlerdir.

221 Kaymaz, Pervâne için "Anadolu Selçuklu Devleti'nin inhitat yıllarımı yaşadığı karanlık devirde, bu devrin kendisine has şartlarından yararlanarak kudret ve nufuz kazanmış ve bütün bir devlet teşkilâtı, hatta, doğrudan doğruya saltanat makamı üzerinde fiilî hâkimiyet kurmuş olan dikkate şayan bir devlet adamıdır" demektedir (Pervâne, S. 1).

222 Aksarâyî, S. 45-46.

223 Aksarâyî, S. 41 .

224 Aksarâyî, S. 89.

225 Aksarâyî, S. 97.

226 Aksarâyî, S. 209, 217-218, 251-252. 
emredilmektedir ${ }^{227}$. Necmü'd-dîn Mahmud'a ait diğer belgede ise, müstevfîlik makamının saltanatın direği olduğu, onun divân ile vilâyet ve beldelerin malî işlerini memurlara tefviz, maden ve tuzlalara liyakatli âmiller tâyin etmesi, mülklerin istihrâc ve muhafazasında gayret göstermesi emredilmektedir ${ }^{228}$.

Aksarâyî, müstevfîlerden başhca tâyinleri münasebeti ile bahsetmiştir ${ }^{229}$. Bazan bu makamda bulunanlar hükümetin en yüksek iki makamı olan vezirlik'e ve niyâbet-i saltanat'a tâyin ediliyordu. Gerçekden Emin ü'd-dîn Mikâil, mansab-ı istifấ'dan nâibliğe ${ }^{230}$, Mecdü'ddîn Mehmed ise vezîrliğe yükselmişlerdir ${ }^{231}$. Aksarâyî istifâ- $i$ memalik makamını işgal edenlerin görev ve yetkilerinden ziyade kişilikleri ve icraatlan üzerinde durmuş, Mecdü'd-dîn Mehmed ve Celâlü'd-dîn'in seçkin ve kültürlü olduklarını belirtmiştir ${ }^{232}$. Şerefü'd-dîn Osman ise vergi toplamak ile görevli olduğu bölgede haksızlık yapmıștır. Hattâ onun devrinde şeyhler zaviyelerini rehine etmeğe mecbur kalmışlardır ${ }^{233}$.

Diğer taraftan Aksarâŷ̂’nin divân-ı istifâ' daki dört müstevfîden ikisinin dalay, ikisinin de incu vergileri ile meşgul olduğundan bahsetmesi ${ }^{234}$ Selçuklu Devleti'nin son devirlerinde Moğollar'in kendi teşkilâtlarını yerleştirdiklerini göstermektedir.

Tuğraî: Tuğra divanı devletin hârici ve dahilî yazışmalarını düzenleyen müessesedir. Sultan namına yazılan bütün ferman, menşur ve misâller (emîrnâmeler), ecnebi hükümdarlara ve memleket dahiline gönderilen fetihnâmeler, muahedeleri kaleme almak başlıca görevidir ${ }^{235}$.

Aksarâyî, tuğrẩ’lerden ${ }^{236}$ nadiren bahsetmiş ${ }^{237}$ görev ve yet-

227 Turan, Vesikalar, S. 3-4. Vesika II.

228 Turan, Vesikalar, S. 5-6. Vesika III.

229 Aksarâyî, S. 40-41, 65, 73, 149, 210, 236.

230 Aksarâyî, S. 65 .

231 Aksarâyî, S. 73.

232 Aksarâyî, S. 89, 97.

233 Aksarayî, S. 223-224.

234 Aksarâyi, S. 180 ve 228.

235 İslâm devletlerinde mevcud olan inşâ divânı, Selçuklular devrinde tuğra divânı adını almışdır. Bunun sebebi, bu divândan sultan namına çıkan belgelerin, eski Türk hâkimiyet telâkkisi mucibince tuğrayı ihtiva etmesidir (Turan, Vesikalar, S. 23).

236 Oğuz Yabgu Devleti'nde Yabgular'ın mühürlerine ve fermanlarma tuğrağ (tuğra) deniliyordu. O devirde bu kelimeyi diğer Türkler bilmiyorlardı (Sümer, Oğuzlar, S. 53).

237 Aksarâyî, S. 62, 218, 249. 
kilerine dair bilgi vermemiştir. Yalnız tuğrâ̂̂ Şemsü'd-dîn Mahmud'un Hulagu'yu ziyarete gittiği, iltizam ve vezâret için yarhk elde ettiği kayıthdır ${ }^{238}$.

Müşrif-i memâlik: Müşrif-i memâlik "aslî defterlerin düzeltilmesi, memleketlerin yazılması, divan (hazine) mallarının meydana çıkanlması, beldelerin ahval ve muamelâtı ile, hanedana ait binaların gelir ve masraflarının bilinmesi için gayret gösteren, takrir ve beratlar üzerine nişan koyan” görevlidir ${ }^{239}$.

Aksarâyî, müşrif-i memâlik'ten ancak tayin münasebeti ile bahsetmiştir ${ }^{240}$. Eserin sonlarında müşrif-i memâlik Seyyid Hamza'nun divân toplantılarına katıldığı ve Moğollar tarafindan idam edildiği hakkında bir kayıt vardır ${ }^{241}$.

Eserde, şer'i kanunlar dışında örfî davalara bakan mahkemenin başkanı olan ve sultanın emri ile emîrleri tevkif etmek ile görevli ${ }^{242}$ emir-i dâd hakkında az (emîr-i dâd Fahrü'd-dîn Ali'nin İlhanlılar'a elçilik ile gönderilmesi ${ }^{243}$ ve emir-i dâd Eminü'd-dîn'in üstâdü'd-dâr ve mütevelli-i evkaf-ı memalik görevlerine tâyini) ${ }^{244}$ ve askerî şahıslarm iktâlarına, gelirlerine, maaşlarına ve birliklerin teçhizatının kayıt ve kontroluna bakan divân'ın başkanı emir-i arız ${ }^{245}$ hakkında hị̧ bilgi yoktur.

Diğer yüksek makamlara gelince, şimdiye kadar araştırıcılarm görev ve yetkileri hakkında kesin bir sonuca varamadıkları nâzır-ı memâlik, görünüşe göre, malî denetim müessesesinin başıdır ${ }^{246}$. Aksarâyî, nâzır-ı memâlik'i zikretmiştir ${ }^{247}$.

238 Aksarayî, S. 62. Bu zatın tuğrai'liğe tayin menşuru: Turan, Vesikalar, Vesika XXIX.

239 Turan, Vesikalar, S. 20, Vesika XXVI.

240 Aksarâyî, S. 74, 89, 93, 140, 279.

241 Aksarâyî, S. 286.

242 Turan, Vesikalar, S. 132. Selçuklu iktâlarında ve ikâ askerleri arasındaki şer'iat haricindeki davalara bakan divan-ı mezâlim Türk ve İslâm hukuk ve örflerinin sonucudur (S. 47).

243 Aksarâyî, S. 41 .

244 Aksarâyî, S. 88 .

245 Uzunçarşılı, Medhal, S. 105.

246 Turan, Vesikalar, S. 177-18. Divân-ı nazar-ı memalik'in Büyük Selçuklu Imparatorluğu ve Harizmşahlar teşkilâtındaki rolü de tam olarak anlaşılmamışdır. Gerçekten H. Horst malî işlere bakan bu divânın yalnız bir belgede zikredildiğini, görevleri hakkında bilgi olmadığını kaydetmiștir. (Die Staatsverwaltung Der Grosselguqen und Horazmsahs, Wiesbaden, 1964. S. 39; Tenkidi ve tercümesi: M. A. Köymen, Selçuklu Devri Türk Tarihi Araştırmaları, Tarih Araştırmalı Dergisi, II (1966), S. 328.

247 Aksarâyî, S. 93. 
Evkâf-ı memâlik, görünüşe göre sosyal hayatta önemli rolü olan vakıfların düzenlenmesi ve organizasyonu için kurulmuştur. Kadı'lkudât mevkiinde bulunan kimse aynı zamanda vakıflara nezaret ediyordu. Ancak zaman zaman bu makama müstakil tâyinler yapılmıș ${ }^{248}$,

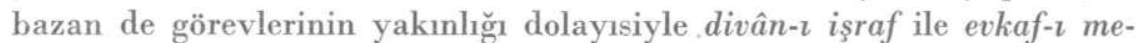
malik veya tuğra mansıblarının aynı şahısın uhdesine verildiği olmuştur ${ }^{249}$.

Müsâmeretii'l-Ahbâr'da evkaf-ı memalik'e dair en önemli kayıt yazarın Gazan Han'm yarlığı ile mütevelliliğe tayini hususundaki pasajdır. Bu münasebet ile mütevellinin harab olan kervansarayları tamir ettirmek görevi ile mükellef olduğunu da öğreniyoruz ${ }^{250}$.

İdare teşkilâtına ait pek az bilginin bulunduğu eserde mutasarrıf ${ }^{251}$ tâbiri geçmektedir. $\mathrm{Bu}$, o devirde iktâ sahibi anlamına geliyordu.

Aksarâyî, divânlarda ve vilâyet teşkilâtında çalışan vazifelilerden nuvvâb (nâibler) ve kârdârân (memurlar) olarak bahsetmiştir. Nuvvâb, bilindiği gibi, merkezde veya taşradaki yüksek memurların vekilleridir. Aksarâyî, nuvvâb'dan tâyinleri ve gönderilen fetihnâmeler dolayısı ile bahsetmiş ve hemen daima kârdârân ile beraber kullanmıştır ${ }^{252}$. Bundan başka küttâb (kâtibler) ${ }^{253}$ âmil (geniş mânâda memur, dar mânâda tahsildar $)^{254}$ ve debîr (kâtib) ${ }^{255}$ deyimleri de vardır. Memurların kavmî durumuna da değinen yazar özellikle İlhanlı devlet adamlarının maiyetinde Anadolu'ya gelen geniş bir kadronun varlığını belirtmekte, bunların İran'a veya başka ülkelere mensub olduğunu yazmaktadır: Taberistan, Kirman, Horasan, Irak-ı Acem, Erran, Gürcistan $\mathrm{v} . \mathrm{s} .^{256}$.

\section{ASKERİ TEŞKILÂTT}

Türkiye Selçuklu Devleti'nin karakteristik vasfi askerî bir bünyeye sahib olmasıdır. Bu bakımdan ordu devlet ve toplum hayatında

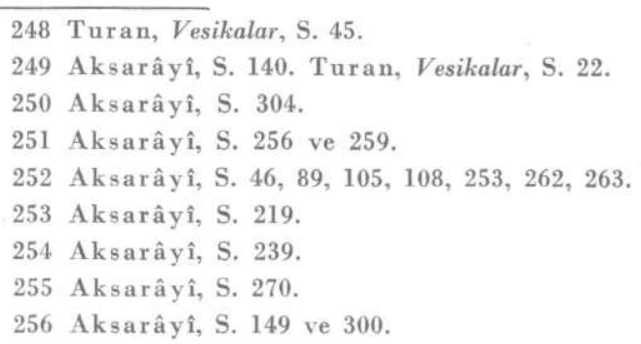


önemli bir mevki işgal ediyordu. Devlet teşkilâtında da askerî kadrolar sivil kadrolara nazaran daha genişti. Devlet ileri gelenlerinin büyük bir kısmı "ehl-i seyf"den olup emîr rütbesini taşıyordu.

Devrimizde olduğu gibi o zaman da silâhlı kuvvetler idare ve harekât gibi iki ana şube ile yöneltiliyordu. Orduya ait bütün idarî işlere büyük divana bağlı olan divân-ı arz bakıyordu (Gördügümüz gibi Müsâmeretï'l-Ahbâr'da bu divana ait bilgi yoktur). Harekât işleri ise, devletin yönetiminde birinci derecede söz sahibi şahsiyetlerden olan beylerbeyi'nin uhdesindeydi.

\section{Ordunun bünyesi}

F. Köprülü, Türkiye Selçuklu Devleti ordusunun yedi şubeden meydana geldiğini yazmıştır: a) Merkezde sultanın şahısına bağlı olan kuvvet, Bunlara "müfred, gulam, mülâziman-1 yatak" deniliyordu. Sarayda vazifeli olan serhenkler, candarlar ve perdedarlar bu zümreye dahildiler. Meselâ XIII. yüzyılda bunların sayılarının beşyüz kadar olup, menșelerinin de Kazvin'li, Deylem'li ve Frank olduğunu biliyoruz. b) Kayseri başta olmak üzere Sivas, Harput, Develi-Karahisar, Niksar, Malatya, Erzincan, Niğde, Lâdik, Honas gibi önemli askerî merkezlerdeki muhafaza kuvveti. Bu merkezlere bağh olan mıntıkalardaki iktâ sahipleri, Türkmenler ve müstahkem mevkilerdeki daimî kuvvetlerin komutanları o mıntıkanın subaşı (serleşker)sına tâbiydiler. c) Merkezde veya kendi muntıkasında bulunan büyük iktâ sahibi devlet ricâlinin şahıslarına bağlı olan gulâm veya ücretli askerlerden mürekkeb kuvvet. d) Küçük iktâ sahiplerinin maiyetindeki kuvvet (Tımarłı sipahiler). e) Uclarda ve beylerinin emrindeki kuvvet. Barış zamanında dahi komşu devletlere (Bizıns, Ermeni ve Gürcüler'e) akın yapan bu Türkmenler'in firsat buldukça isyan çıkardıklarını da biliyoruz. f) Harp zamanında fazla askere ihtiyaç olunca Türkmenler'den veya ülke dahilinde yaşayan yabancı irklara mensub halktan ücret ile tutulanlar. g) Türkiye Selçuklu Devleti’nin vasallığını kabul eden veya bir anlaşma gereğince harp zamanında belli miktarda asker vermeği taahhüt eden müslüman veya hirıstiyan devletlerin gönderdikleri kuvvetler ${ }^{257}$.

Aksarâyi’nin söz konusu ettiği devirde Türkiye Selçuklu Devleti ordusunu meydana getiren şubelerde Moğul işgali sebebiyle- değişiklik

257 Köprülü, Bizans Müesseseleri, S. 241 ve dv. 
olmuştur. Şüphesiz sultanın şahsına bağlı olan "hassa ordusu" muhafaza edilmiştir. Gene müstahkem mevkilerdeki kuvvetlerin'de muhafaza edildiğini biliyoruz. Türkmenler'in ise -bu devirde daimî iğtişaş unsuru olduklarından- Selçuklu ordusunun kadrosunda oldukları düşünülemez. Fakat ücretli askerlerin ordudaki varlığının devam ettiği anlaşılmaktadır. Askerî merkezlerdeki kuvvetler ile büyük iktâ sahipleri emrindeki kuvvetlerin ise sayısının azaldığı muhakkaktır. Ordu mevcudunun 1277'ye kadar olan yıllarda azalmasının ve devletin yıkılışına tekaddüm eden senelerde ordunun hemen tamamen ortadan kalkmasının en önemli sebebi, iktâ sisteminin Moğol işgali ile sarsılmasıdır. Selçuklu ordusuna önemli sayıda asker veren iktâ mıntıkalarının bilhassa Kılıc Arslan IV. devrinde mülk haline getirilmesi, ordunun sonu olmuştur $^{258}$. Esasen Moğollar'ın da Selȩuklu ordusunu kontrol altında tuttukları ve kemiyet olarak büyümesine mâni oldukları muhakkaktır $^{259}$.

Bu itibarla bu dönemde Selçuklu ordusundaki boşluk Moğol askeri tarafından doldurulmuştur. Harekât ortaklaşa yürütülmüş, karma Selçuklu-İlhanlı ordusu bazan Türk, bazan Moğol komutanların yönetimine verilmiştir.

$\mathrm{Bu}$ devirde Selçuklu ordusunun vazifesi hemen tamamen ülke dahilindeki isyanları bastırmağa inhisar etmiştir. Bu itibar ile Moğollar'ın kuvvetlerini harekâta iştirak ettirmeleri tabiidir. Aksarâyî, ortak Selçuklu-İlhanlı harekâtına dair müteaddit örnekler vermiştir. Batıdaki uc vilâyetlerinde çıkan karışıklık üzerine "Leşker-i Moğol ve Müslüman" harekete geçmiş ve isyanı basrtırmıştır ${ }^{260}$. Pervâne Mu'inü'd-dîn'de Moğol ve Tacik (Müslüman Anadolu askeri) birliklerinden müteşekkil bir kuvvet ile Karamanoğulları üzerine yürüdü ${ }^{261}$.

258 Pervâne'nin ölümünden (1277) sonra Ilhanlılar Anadolu'yu işgal ettiler; Selçuklu Devleti ve ordusu da fïlen ortadan kalkdı, iktâ idaresi de yıklımış oldu. Bu tarihten itibaren Aksaray î'nin Anadolu'da vukuundan bahsettiği isyan ve kargaşalıkların başlıca âmili meslek ve maişetlerini kaybeden iktâ sahipleridir (Turan, Iktâ IA).

259 Kösedağ savaşı surasında (1243) 80. 000 olan Türkiye Selçuklu Devleti Moğol tâbiyetine girdikten sonra tedricen azalmış ve zamanla birkaç bin kişilik bir kuvvet haline gelmişdir. Buna mukabil Anadolu'daki Moğol askerleri de artmışdır. Bu devirde Selçuklu ordusu 50006000 kişi kadardı. Beylerbeyi Hatıroğlu'nun emrinde 4000 kişi vardı. Pervâne Sinob'u Dânişmend ili, Niksar ve Samsun çevresinden topladığı 4000 kişi ile fethetti (Kaymaz, Pervâne, S. $238,255,84$.

260 Aksarâyî, S. 71 .

261 Aksarâyî, S. 111. 
Gene Pervâne, Memlûk sultanı Baybars'ın Anadolu'ya gelmesi üzerine Tacik-ve herhalde ücretli askerler ile- harekete geçti ${ }^{262}$; daha sonra Moğol noyanları ile beraber uc vilâyetlerine yürüdü ${ }^{263}$. K e yh a t u'nun emri üzerine Mesud II. kardeşi Kılıç Arslan’ın isyanımı bastırmak için emrinde Tacik ve Moğol askerleri olduğu halde Kastamonu'ya yöneldi. Türkmenler müttefikleri bozguna uğratmışlar, sultanı esir almışlardır. Sultan bilâhare kurtarılmıştır ${ }^{264}$.

\section{Orduda komuta mevkii ve hiyerarşi}

Selçuklu ordusuna harekât sırasında sultan, vezir ${ }^{265}$ veya melikü'lümerâ unvanı verilen komutan kumanda ediyordu. Bu sırada sultana emirler (ümerâ), serleşkerler (sipehdârân-ı memâlik), reisler (rüesâ) ve ileri gelenler (mu'teberân) refakat ediyorlardı ${ }^{266}$. Harekât emrini ekseriya ilhan veya Anadolu'da görevli şehzade veya noyanlar veriyorlardi ${ }^{267}$.

Beylerbeyi, Türkiye Selçuklu Devleti'nin merkezinde en yüksek askerî makamı işgal ediyordu. ${ }^{268}$. Beylerbeyi protokolda bütün devlet teşkilâtı içinde askerî ricalin en ön safindaydı ${ }^{269}$. Ancak, uclarda üç -Keykûbad I.ın güney sahillerini fethetmesinden sonrabeliki de dört olmak üzere uc beylerbeylikleri vardır. Sultan tarafindan sefere gönderilen ordunun başındaki kumandana “melikü'l-ümerâ" unvanı veriliyordu ${ }^{270}$. Kaynağımızda geçen "sipehdâr-ı bü-

262 Aksarâyî, S. 113.

263 Aynı yer.

264 Aksarâyî, S. 170 ve dv.

265 Aksarâyî, S. 112).

266 Aynı yer.

267 Aksarâyî, S. 130.

268 Sümer, "Oğuzlar'da bir memuriyet olarak beylerbeyinin mevcudiyetinin malûm olmadığını, ancak Salur-Kazan Bey’in bazen beylerbeyi unvan ile de anıldığın yazıyor (Oğuzlar, S. 387). Türk-İslâm devletlerinde devlet erkânının protokoldaki yerini tâyin ve tasrih etmek sultanın yetkileri cümlesindendi. Nitekim Izzü'd-dîn Keykâvus I. devrinde emir-i meclis'lik makamı-sultanın bu makamı işgal eden zata itimat ve teveccühü sebebiyle-en yüksek askerî mevki olan beylerbeyi'nin üstünde tutulmuştur. (Kaymaz, İdare Mekanizması, I, S. 142). Sultan Celâlü'd-dîn Hârizmşah'da vezîri Şerefü'l-mülk'e protokolda-seleflerininkine nazaran- daha dûn bir mevki vermişti (Nesevî, Histoire du Sultan Djelal Ed-Din Mankobirti, S. 292).

269 Kaymaz, Idare Mekanizması, I, S. 126.

270 Kaymaz, Idare Mekanizması, I, S. 126). 
zürg" veya "emîr-i büzürg" tâbiri ise uc beylerbeyliği'ne tekabül etmektedir ${ }^{271}$.

Müsâmeretü'l-Ahbâr'da beylerbeylerinden daha çok tâyinleri ${ }^{272}$ münasebetiyle bahsedilmektedir ${ }^{273}$. Beylerbeyinin, diğer devlet erkânı gibi iktâları var idi. Meselâ Hatıroğlu Şerefü'd-dîn, Niğde muktaı idi $^{274}$. Beylerbeylik makamına "emâret-i beylerbeyi" deniliyor ve 0 , "sipehdâr-1 kebîr"275, "sipehdâr-1 memleket"276 unvanını da taşıyordu. Beylerbeyi icraatından dolayı Moğollar’a karşı sorumlu idi ve yarguya çekilebiliyordu.

Ue beylerbeyliği "emaret-i vilâyet-i uc ${ }^{9277}$ olarak zikredilmektedir ${ }^{278}$.

Vilâyetlerde serleşker ${ }^{279}$ vardı. Bunlar aynı zamanda emîr-i leşker-i vilâyet $^{280}$ veya sipehdâr-ı vilâyet ${ }^{281}$ olarak da zikredilmiştir. Serleşker'ler görevli bulundukları vilâyetin en yüksek askerî âmiri idii ${ }^{282}$. Bunlar aynı zamanda emniyet ve düzeni sağlamak ile mükelleftirler ${ }^{283}$. Savaş zamanında orduya katılıor, sultan'in veya melikü'l-ümerâ lâkabını taşıyan başkumandanın maiyetine giriyordu ${ }^{284}$.

Serleşkerlerin emrinde kale kütuvali (muhafizı) ${ }^{285}$ bulunuyordu.

271 Kaymaz, Pervâne, S. 210 ve dv.

272 Bu devirde Yavtaș, Kont, İstabl, Hatıroğlu Şerefü'd-dîn ve Azizü'd-din beylerlik görevinde bulundular. Bunlardan Kont Istabl hırıstiyandır. Türkiye Selçuklu Devleti'nde ihtida eden devlet adamları olduğu gibi , dinini muhafaza edenler de vardır (Fazla bilgi için bk. Kaymaz, İdare Mekanizması, I, S. 131 ve 152) .

273 Aksarâyî, S. 40, 49, 89 .

247 Aksarâyî, S. 74 .

275 Aynı yer.

276 Aksarâyî, S. 82 .

277 Aksarâyî, S. 74 .

278 Aksarâyî, S. 132 .

279 Aksarâyî, S. 63, 98, 101, 113, 130.

280 Aksarâyî, S. 191.

281 Aksarâyî, S. 100, 111, 281.

282 Sümer, Oğuz Yabgu Devleti'nde sü-başı'nın ordu komutanı anlamına geldiğini ancak sayısının bilinemediğini, Selçuklular'ın bu memuriyeti ve kelimeyi Anadolu'ya getirdiklerine işaret ediyor (Oğuzlar, 52).

283 Aksarâyî, S. 113.

284 Aksarâyî, S. 130 .

285 Aksarâyî, S. 71, 107, 108, 254. 
Kütuval'in maiyetinde hâris, durc-dâr, diz-dâr $\operatorname{vard}^{286}$.

Yüksek rütbe sahibi kumandanlardan olan emîrü-s-sevâhil ${ }^{287}$ veya melikï's-sevâhil ${ }^{288}$ in görev ve yetkileri hakkında eserde bilgi yoktur. Ancak melikü's-sevâhil'likte bulunmuş olan Bahaü'd-dîn ve HocaYunus'un asî Türkmenler'i tenkil etmek ile görevlendirildikleri, fakat başaramadıkları yazılıdır ${ }^{289}$. Bunların emrinde donanma bulunuyordu ${ }^{200}$. Bu devirde Selçuklu donanmasının varlığını Pervâne'nin 1266 yılında, Sinob harekâtı sırasında kullandığı gemilerin varlığından anlıyoruz. Gerçekten o, kara tarafından sonuç alamayacağını anlayınca, şehri donanma ile abluka etmiş, bin kadar askeri gemilere bindirerek hücuma geçirmiş Sinob'u zapt etmiştir ${ }^{291}$.

Sultan ve kumandanlar haberleşme için kussâd (kâsıdlar-haberciler) kullanyorlardı. Kussâd, bir sultanın cülûsu haberini ülkenin her tarafina bildirmek, vilâyetlere fetihnâme ${ }^{292}$, emsile (misâller) ve fermanlar ulaştırmak ${ }^{293}$, devlet erkânı arasında haberleşmeyi temin etmek ${ }^{294}$ ve istihbarat yapmak ile ${ }^{295}$ görevliydiler ${ }^{295}$ a.

286 Turan'ın neşrettiği Konya kalesi Kütuvali'nin tâyinine ait belgeye göre, onun görevi kaleyi muhafaza ve murakabe etmek, evlerin, anbarların, zahire ve silâhlarının yazılması için çalışmak kale halkını müreffeh ve rahat tutmak, uygunsuz hareket edenlere ceza vermek, kale muhafizlarma ihtimam göstermek, kaleye kefilsiz girilmesini engellemek, kale muhafizlarım kapı ve burçlarda bulundurmaktı (Vesikalar, S. 34. Vesika XXXII).

287 Köprülü'ye göre, Türkiye Selçuklu Devleti teşkilâtında XIII. yüzyılın ilk yarı'mın sonlarında Reisü'l-bahr unvanlı büyük bir memur devletin Karadeniz deki en önemli denizüssü Sinop'ta görevliydi. XIII. yüzyılın ikinci yarısında Selçuklu ümerâsı arasında önemli mevkii olan emirü's-sevâhil Hoca Yunus ve melikü's-sevâhil Bahä̈'d-dîn'in isimleri başlıea kaynaklarda vardır. Köprülü'nün tahminine göre reisü'l-bahr unvan Moğol devrinde evvelâ emirï's-sevâhil'e sonra da melikü's-sevâhil şekline girmiştir (Bizans müesseseleri, S. 207). Diğer taraftan P. Wittek'in 676 (1277-78) ylında Alanya'da bir camiin kitabesinde emirü'l-sevâhil ve gene başka bir kitabedeki melikü's-sevâhil ibaresi bulunduğu kaydı (Menteşe Beyliği, Ankara, 1944, S. 30) bu memuriyetin devletin Akdeniz kıylarını kapsayan bölümünde de bulunduğunu gösterir. Esasen Bahaü'd-dîn ve Hoca Yunus bu mintıkada görevliydiler.

288 Aksarayî, S. 74, 112, 122.

289 Aksarayî, S. 112, 122.

290 Uzunçarşılı, Medhal, S. 130.

291 Aksarayî, S. 83. Bu harekât sırasında gemilere maneınık yerleştirildi (Kaymaz, Pervâne, S. 84).

292 Aksarayî, S. 72 .

293 Aksarâyî, S. 103.

294 Aksarayî, S. 68.

295 Aksarâyî, S. 105.

295 a Selçuklular'da islâmî unvan ve lâkablardan başka Türkçe unvanlar da vardır. Bun- 


\section{Orduda at ve silâhlar}

Ordunun genel olarak süvârilerden mürekkep olduğu nazarı itibara alınır ise, atın ${ }^{296}$ orduda işgal ettiği mevkiin önemi anlaşılır.

Özellikle sultanlar ata büyük önem veriyor ve iyi birer süvari oluyorlardı. Meselâ Keyhüsrev III. çok iyi ata binerdi ${ }^{297}$. Kılı̨̧ Arslan IV. ise Aksaray sarayı'nın merdivenlerini at ile iner ve çıkardı. Maiyetinin bunu menetmesine rağmen onlan dinlemiyordu ${ }^{298}$. Bu durumda o devride at yetiştiriciliğinin çok ilerdiğini ve at neslinin de islâh edildiğini anlıyoruz. Gerçekten Pervâne’nin Moğollar tarafindan öldürüleceğini anlayan havâssı'ndan biri ona özel şekilde yetiştirilmiş dört arab atı getirdi. On gün on gece koşabilecek kudretleri olan bu atlar ile kaçmasını teklif etti. Pervâne bu teklifi kendisi kaçtığı takdirde Moğollar tarafindan halka zulüm yapılacağını ileri sürerek, red$\operatorname{det} \mathrm{ti}^{299}$.

Bilindiği gibi, at, o devirde kıymetli bir hediye addediliyordu. Nâib-i sultan Emirşah, Niğde civarındaki bir kalede tahassün eden Türkmenler'in isyanını bastırmak için yürüyünce, Türkmenler ona ve beraberindeki Moğol kumandanına atlar gönderdiler. Emîrşah, at hediye edilmesine rağmen kaleyi ald ${ }^{300}$.

Türkiye Selçuklu Devleti ordusu devrin bütün klasik silâhlarma sahipti ${ }^{301}$.

\section{Yaylak ve kışlak yerleri}

Yaylak ve kzşlak'lar savaş zamanı dışında, ordu kumandanlarının ve efradının istirahate çekildikleri yerlerdir. Yaylak ve kışlak'klarda ordu mensubları bulunduklan bölgede dağıhyorlardı. Bu bakımdan

lar, Göktürk ve Uygarlar'dan. Karahanlılar'a ve Selçuklular'a intikal etmiştir. Bu unvanlar Türklere ve menşei Türk olan makamlara inhisar etmiştir. Emîrlere uluğ hass alp uğurlu, sübaşı beg,; uc kumandanlarına sipeh-bad-i diyâr-i uc, kale muhafızlarına kutluk bilge hâss kütüvâl beg, emîr-i arız için kutluk bilge inanç âriz beg gibi (Turan, Vesikalar, S. 174).

296 At için: bk: S. Batu, Türkler ve at, Ankara, 1952; Sümer, Oğuzlar, S. 396; Turan, Selçuklular, S. 269. Türkler'də at için şimdilik bk.E. Esin, The Horse in Turkic Art, CAJ, (1965) X / $3-4$ s. $67-227$.

297 Aksarâyî, S. 88 .

298 Aksarâyî, S. 82 .

299 Aksarayî, S. 117.

300 Aksarayî, S. 254.

301 Silâhlar için bk. Uzunçarşılı, Medhal, S. 117; Turan, Selçuklular, S. 268,; Arrade, EI ${ }^{2}$. 
İlhanlı işgali devrinde Moğollar'ın yaylak'ta olmasından faydalanarak isyana tevessül edenler oluyordu ${ }^{302}$. Yaylak ve kışlak yerinin seçimi önemlidir. Moğollar Anadolu'ya geldiği ilk zamanlarda kumandanları yaylak ve kışlak yerlerini Selçuklular'dan soruyorlardı ${ }^{303}$.

Anadolu'da bazı yerlerin hem yaylak, hem kışlak için uygun olduğu anlaşılıyor. Kılı̨̧ Arslan I. yaylak ve kışlak için Birecik, Urfa, Diyarıbakır ve Furat sahilleri'ni tercih etmiştir ${ }^{304}$. Keza Moğollar'in Erzincan'ı yaylak ve kışlàk için seçtiklerini biliyoruz ${ }^{305}$.

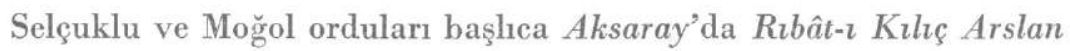
civarında $^{306}$ Delüce $^{307}$, Niksar ${ }^{308}$, Karabük ${ }^{209}$, Sakarya ${ }^{310}$, Konya ${ }^{311}$ y1 kışlak olrak kullanıyorlardı. Yaylak için ise Kırşehir ${ }^{312}$, ve Yabanlu ${ }^{313}$ yu tercih ediyorlardı. Yabanlu ${ }^{314}$ Selçuklu ordularının Doğu ve güneye yapacakları seferlerde toplanma yeriydi. Ruzbe ovast ${ }^{315}$ ise, payitahttan sefere çıkıldığı zaman ilk konaklanan veya ordugâh kurulan yerdir ${ }^{316}$.

\section{Ordu âdetleri}

Orduda disipline büyük önem veriliyordu. Sultan Gıyâsü'd-dîn Keyhusrev III. ve vezîr Fahrü'd-dîn Ali, Cimri isyanı smasında sefere katılmayan emir-i buzürg-i uc (uc beylerbeyi) Ali bey'i ve maiyetini öldürttüler ${ }^{317}$.

302 Aksarâyî, S. 71 .

303 Aksarayî, S. 41.

304 Aksarâyî, S. 27.

305 Aksarâyî, S. 145.

306 Aksarâyî, S. 42 .

307 Aksarâyî, S. 108, 112, 192.

308 Aksarayî, S. 309.

309 Aksarâyî, S. 311.

310 Aksarâyî, S. 312 .

311 Aksarâyî, S. 113.

312 Aksarâyî, S. 85 .

313 Aksarâyî, S. 286, 308.

314 Turan'a göre Sivas-Elbistan arasında olduğu anlaşılmaktadır. (Selçuklular, S. 236).

315 Aksarâyî, S. 69.

316 Ruzbe, Konya'nun 6 km. kuzeyindedir.

317 Aksarâyî, S. 132 . 
Orduda gûy-u ̧̧evgân (çevgan oyunu) rağbettteydi. Hatıroğlu isyanı sırasında katledilen ikiyüz Moğol'un bașı ile askerler çevgan oynamışlar$d_{11}{ }^{318}$.

Savaşlarda rehin usulü de tatbik ediliyordu. İsyan eden Lûlûve

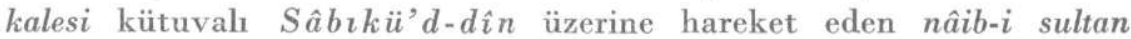
Emirşah, nâiblerinden birini ve küçük oğlunu rehin olarak kaleye gönderdi. Bunun üzerine nâib-i sultan'ın huzuruna gelen kütuval itaatini arzetti. 0 , kaleye döndüğünde rehin olarak gönderilenlere hediye verdi ve dönmelerine müsaade etti ${ }^{319}$.

Bir ülke zaptedildiği veya bir isyan bastırıldığı zaman fetihnâme yazılması usuldendi. Aksarâyî -devrin şartları icabı- daha ziyade bastırılan isyanlar sebebiyle gönderilen fetihnâmeleri söz konusu yapmıştır. Kılıç Arslan IV. devrinde Türkmenler'den Karaman, Zeynü'l-hac ve Bunsuz'un isyanının bastırılmasını takiben hazırlanan fetihnâmeler emin kâsıdlar ile bütün vilâyetlere gönderildi ${ }^{320}$. Cimri isyanının bastırılmasını müteakib her tarafa fetihnâmeler gönderildi ${ }^{321}$. İsyan eden Hatıroğlu Şerefü'd-dîn de zafer kazandığını zannederek vilâyetlere fetihnâme göndermiştiti ${ }^{322}$.

\section{ADALET TESKİLÂTI}

Türkiye Selçuklu Devleti adalet teşkilâtı bütün ortaçağ Türkİslâm devletlerinde olduğu gibi şer’i kaza ile örfî kazanın biribirinden ayrılması esasına dayanır. Bu devirde şerî’at yanında kanun ve örf, yani sadece hükümdarın iradesinden doğan ayr bir hukuk prensibi câriydi ${ }^{323}$. Şer'î mahkemelerde evlenme ve boşanma işleri, nafaka ve miras davaları, her türlü tasarruf anlaşmazlıkları, alacak davaları görülüyordu.

Adalet teşkilâtında reâyâya ait davalara bakan ve kadı'l-kudât'ın bulunduğu sivil mahkemeler, ordu mensuplarının davalarına bakan

318 Aksarâyî, S. 102-103. Köprülü, top ve çevgen oyunlarının Türkiye Selçuklu sarayında de rağbette olduğunu, Izzï'de-din Kaykâvus'un haftada bir, Alaü'd-din Keykûbad'ın iki defa teşrifat usullerine bağh kalarak oyun oynadıklarına değiniyor (Edebiyat araşturuaları, s. 84).

319 Aksarâyî, S. 254 .

320 Aksarâyî, S. 72 .

321 Aksarâyî, S. 132 .

322 Aksarâyî, S. 104-105.

323 İnalcık, Osmanlı Hukukuna giriş, SBFD, XII (1958), S. 102. 
ve başında kadı-i leşker'in bulunduğu askerî mahkemeler vardı. Yukarıda da işaret ettiğimiz üzere, örfî davalara bakan mahkemeye ise Büyük Divân üyesi olan emir-i dâd başkanlık ediyordu.

O. Turan neşrettiği kadı tâyinine ait menşurlardan kadı'l-kudât ve kadı'i leşker'lik mansıblarının bazan bir şahsın uhdesine -Konya ve başka bir şehrin kadılığı da ilâve edilerek- verildiğini öğreniyoruz ${ }^{324}$.

Aksarâyî kadı'l-kudât memuriyetini zikretmemiş, sadece Konya kadısından ve kadı'l-asakîr'den bahsetmiştir. Mansıb sahiblerinin başka isimler taşımalarından bu iki memuriyetin aynı şahsın uhdesinde olmadığı anlaşılmaktadır ${ }^{325}$.

Yazar, kadı'l-asâkir'in müradifi olan kadt-i leşker ${ }^{326}$ tabirini kul lanmıștır. Onun, bașta Konya ${ }^{327}$ olmak üzere Aksaray ${ }^{328}$, Kayseri ${ }^{329}$, Sivas $^{330}$, Tokat ve Niksar ${ }^{331}$, Karahisar ${ }^{332}$ kadılarından $^{333}$ bahsettiği halde kadı'l-kudât tabirini kullanmamasının sebebi anlaşılamamaktadır.

Aksarâyî, ismen de bahsettiği bu kadıların ilim, irfan ve faziletlerini övmüş, bu arada kadı Nuru'd-dîn Yanbûînin, Keyhüsrev III. in talim ve terbiyesi ile göverlendirildiğini de yazmıştır ${ }^{334}$.

324 Turan, Vesikalar, S. 41.

325 Aksarâyî, S. 90 ve 121. Nitekim Turan'da Selẹuklu devri kaynaklarında müstakil olarak kadıasker'lerin zikredildiğini bazen de Konya kadısının kadıasker olduğuna dair kayıtların olduğunu yazıyor (Vesikalar, S. 46).

326 Aksarâyî, S. 72 .

327 Aksarâyî, S. 90 .

328 Aksarâyî, S. 90 ve 306 .

329 Aksarâyî, S. 90 ve 121 .

330 Aynı yer.

331 Aksarâyî, S. 90.

332 Aynı yer.

333 Kadı'nın haiz olduğu velâyet-i kaza yalnız hüküm vermeğe şâmildir, bu bakımdan kadı'nun görev ve yetkileri hüküm verme (inşâ) kudretinin sahası içindedir. Infâz kudreti ise icrâ organının yetkileri cümlesindendir. Bununla beraber velâyet-i kaza bazan lafız, ahval ve örfe göre tevzi ve tahdit edilebilir. Bu da zamana ve mekâna göre değişebilir ve genel olarak şer'i hükümlere inhisar eder (E. Mardin, Kadt, IA). Türkiye Selçuklu Devleti'nde her kadı kendi kaza dairesinde bulunan vakıflara nezaret ediyordu. Kadı'l-kudât ise bütün Selçuklu ülkesinin vakıflarının nazırıdır (Turan, Vesikalar, S. 45). Selçuklu kadısı velâyet-ui kaza'ya ilâveten vakıf konusunda da icraî yetkiler ile de mücehhezdi.

334 Aksarâyî, S. 88. 
Cezalandırma Şekilleri: Sultanın suçlu olduğuna karar verdiği ve katledilmesini emrettiği şahısların cesedleri bazan köpeklere yediriliyordu. Kılıç Arsılan IV., kardeşi İzzü'd-dîn'in dayısı Kirhaye'nin öldürdükten sonra cesedinin köpeklere atılmasını emretti ${ }^{335}$. Müstevfî Abdurrahman'1 öldüren bir batınî de yakalanınca, maktulun eshab'ı tarafindan kisas olarak öldürüldü ve cesedi köpeklere yedirildi ${ }^{336}$.

Cimri yakalandıktan sonra, derisi başından ayağına kadar yüzülmüş, içine saman doldurulmuş ve $\cdot$ bir merkebe ters bindirilerek ${ }^{337}$ şehir şehir dolaştırılmıştır ${ }^{338}$

Kılı̨̧ Arslanın devrinde isyan eden Türkmenler'den Karaman, Zeynül-Hac ve Bunsuz yakalandıktan sonra Konya sokaklarında dolaştırıldılar, halkın hakaretine ve hücumlarına mâruz bırakıldılar. Birkaç gün sonra âsiler Konya kalesinin büyük kapısı (dervâze) na asıldılar. Cesedleri Konya sarayı'nın burçlarından atılan oklara hedef oldu $^{339}$.

Türkiye Selçuklu Devleti'nin adalet mekanizması devletin yıkılışına tekaddüm eden yıllarda -özellikle 1277'den sonra- dejenere olmuştur, Aksarâyî, Alâü'd-dîn Keykûbad III. in ikâ ettiği zulümleri ve yaptığı gaspları uzun uzadıya yazmış, bunları devletin tezelzül sebebi addetmiştir.

335 Aksarâyî, S. 82 .

336 Aksarâyî, S. 268 .

337 Anonim Selçuknâme'de Cimri'nin derisinin yüzüldüğü yazılıdır (Metin, S. 62, terc. S. 41). Ayn kaynakta, o devirde suçlunun derisini yüzdükten sonra doldurup teşhir etmek usulünün revâçda olduğuna dair örnekler vardır. İzzü'd-dâin Keykâvus zamanında Sinop'un fethi sırasında esir edilen otuz hırıstiyan kumandanına aynı muamele yapılmıştır (Metin, S.44; terc. S. 28). Gene bk. (Metin S. 47; terc. S. 31).

338 Aksarâyî, S. 132. Cimri kk. da bk. Ş. Tekindağ. Şe m ŝे'd-din Me hmed bey devrinde Karamalılar, Îstanbul Oniversitesi Edebiyat Takültesi Tarih Dergisi, XIV (1964). s. $81-98$.

339 Aksarâyî, S. 72 . 